\title{
HRAD VRTBA A JEHO HOSPODÁŘSKÉ ZÁZEMÍ
}

\author{
LUBOŠ HOBL - PAVEL KODERA
}

\begin{abstract}
Abstrakt: Př́spěvek se zabývá hradem Vrtba, který se nachází v okrese Plzen̆-sever. Absence zděných konstrukci znemožňuje poznání zástavby hradniho jádra. Nicméně dochované terénní relikty odrážejí základni rozvrženi hradního areálu a dovoluji lokalizovat i některé hospodářské provozy v bezprostředním okoli lokality. Pokus o rekonstrukci panství hradu umožňuji písemné prameny, které reflektuji změny těchto struktur na severním Plzeňsku. Součástí článku je i vyhodnoceni archeologických pramenů ziskaných při povrchových sběrech, z nichž nejvýznamnějši je soubor komorových kachlü, resp. reliéfních motivů na nich.
\end{abstract}

Klíčová slova: hrad-hospodářské zázemi - kachle - reliéfní motivy - rybniční soustava - hradní mlýn.

\section{The Vrtba castle and its economic facilities}

Abstract: This contribution is devoted to the Vrtba castle in the Plzeñ-north district. The absence of masonry structures makes it impossible to study the castle core. However, the preserved land relics reflect the basic layout of the castle complex and enable to locate some economic facilities in its close proximity. Furthermore, the reconstruction of the castle and the whole estate is facilitated by written sources conveying the changes in these structures in the north of the Plzen region. The article also contains the assessment of archaeological sources acquired in the course of surface collections, the most important among which is a series of chamber tiles with relief motifs.

Key words: castle - economic facilities - tiles - relief motifs - fishpond system-castle mill.

\section{Úvod}

Pozůstatky hradu Vrtba leží na menším pahorku situovaném v údolní blatné poloze na jižním okraji vsi Vrtbo (k. ú. Horní Bělá), která svým názvem na jméno hradu dodnes odkazuje. Lokalita je vzdálena asi 2,5 km jihozápadně od Dolní Bělé a 17,5 km severozápadně od Plzně.

Zmíněný pahorek, kde bylo umístěno hradní jádro, se nachází v nadmořské výšce přibližně $500 \mathrm{~m}$ n. m. Ve vzdálenosti 100 metrů jižně se nalézá terénní hrana převyšující hrad o zhruba 20 metrů. Tuto hranu odděluje od hradního pahorku mělké údolí pramenné pánve Brodského potoka. Hrad je dnes pokryt porostem převážně listnatého lesa (obr. 1). V něm jsou zastoupeny hlavně javory, buky a duby, jejichž kořenový systém narušuje zděné konstrukce skryté pod dnešní úrovní terénu. V současné době probíhá omlazení tohoto lesa, a proto je v letních měsících lokalita prakticky neprostupná a nepřehledná.

Předkládaný text si klade za cíl přinést souhrn aktuálních poznatků o této lokalitě, včetně prezentace nového zaměření místa a podrobného popisu archeologických nálezů, zahrnujícího rovněž pokus o identifikaci motivů na kamnových kachlích. Pozornost bude také věnována rozpoznatelnému hospodářskému zázemí hradu a jeho situování do širšího regionu.

\section{Stručná historie hradu}

Do psané historie hrad vstupuje poprvé v roce 1316. K tomuto datu nalézáme v zemských deskách zápis, že Sezema „,de Wyrtba“ byl pohnán před soud kvůli zapletení do konfliktu, který měl jeho bratr Racek ,de Byele“ (PZD I, 7). Ze zápisu se tedy dozvídáme, že hrad Vrtba patřil stejnému rodu jako jen několik kilometrů vzdálený hrad Bělá, jenž je v písemných pramenech poprvé uveden $v$ téže době. Oba zmínění sourozenci náleželi k rodině, jejíž příslušníci užívali erb s trojím jelením parožím. Tento rod, později označovaný jako Hroznatovci, měl starobylý původ a rozsáhlé majetky, otec obou zmíněných bratrů však patrně sídlil v nedalekých Krašovicích (Jánský 2009, 51-53). A. Sedláček se dokonce domnívá, že „Krašovice jsou pưvodištěm všech těch, kteři tři jelení rohy na štítě nosili“" (Sedláček 2000, XIII, 228). Tedy nejenom pánů z Vrtby a Bělé, ale rovněž z Krašova, Pušperka, Gutštejna, Nekmíře ad. 


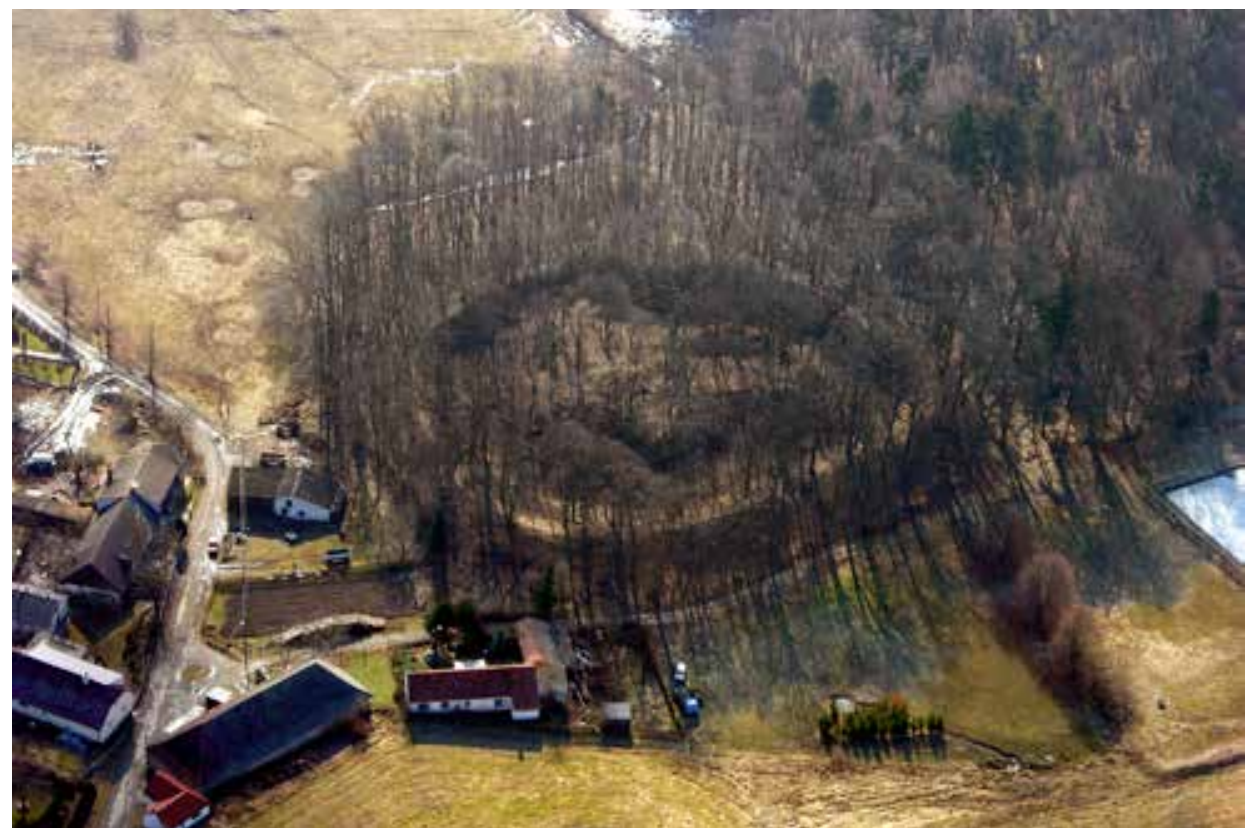

Obr. 1. Letecký snímek lokality od severozápadu. Foto L. Šmejda, 2005.

Abb. 1. Luftaufnahme der Fundstelle aus Nordwesten. Foto L. Šmejda, 2005.

Rod se hlásil k velmoži Hroznatovi († 1217), zakladateli klášterů premonstrátů v Teplé a premonstrátek v Chotěšově. $\mathrm{V}$ duchu rodové tradice, ale i běžného středověkého usu, podporovaly klášterní instituce také panské rody sídlící v námi sledovaném regionu. Zatímco páni z Bělé v polovině 14. století udržovali kontakt s dominikánským klášterem v Plzni a našli v něm i místo posledního odpočinku (D[vorsk]ý 1874,177 n), ${ }^{1}$ páni z Vrtby patrně tíhli spíše ke klášteru cisterciáků v Plasích. Svědčí o tom listina z roku 1344, v níž Sezema z Vrtby (Zesina de Wirtpa) „zbožné muže konventu“ nazývá „,nejdražšimi práteli“ a se souhlasem svých synů Peška a Sezemy odkazuje plaskému klášteru 2 kopy grošů ve vsi Chotíkov (Gothycaw) - jednu pro spásu duše své, druhou pro spásu duše manželky Markéty, která byla $v$ tomto klášteře pohřbena. Zároveň si Sezema vymiňuje i své pohřbení tamtéž (RBM IV, 574). ${ }^{2}$

Zápisem jsou zmíněni rovněž Sezemovi synové - Pešek (Petr) a Sezema. O dvě desetiletí později je Petr rytíř z Vrtby (de Wiertpa) k roku 1364 uváděn jako patron kostela v Krašovicích (LC I/2, 45). V témže roce postupuje kladrubskému klášteru vsi Kyjov a Malesice směnou za Lubenec (Kočka 1932, 124), ${ }^{3}$ tedy podobně jako v prŕípadě výše zmíněného Chotíkova se jedná o majetek na severozápadním okraji dnešní Plzně.

Zajímavé údaje k vrtbovskému panství v poslední čtvrtině 14 . století poskytuje berní rejstř́ík Plzeňského kraje z roku $1379 .{ }^{4} \mathrm{~V}$ indexu registru pod číslem LXXX nacházíme „zboži pánů Petra a Sezemy“, a přestože predikát není uveden, můžeme se důvodně domnívat, že se jedná o výše zmíněné bratry (Bernaregister, 22; o rozsahu uvedené majetkové držby bude pojednáno

1 Některými autory jsou považováni dokonce za zakladatele tohoto kláštera (např. Kočka 1932, 112).

2 Nicméně v nadcházejícím období byli páni z Vrtby pohřbíváni rovněž v klášteře v Chotěšově, v jehož nekrologiu je uvedeno pět členů rodu (Jánský 2009, 188).

3 Nedaleko Lubence založil Petr z Vrtby hrad Petršpurk, nazývaný také Petrohrad (Sedláček 2000, XIV, 345).

4 Jedná se však o pramen částečně fragmentární, jehož interpretace není vždy zcela jednoznačná (k tomu podrobně Hojda-Pešek 1979, 103157, k neúplnosti pramene 129; srov. také Rožmberský 1999). 
dále). Hrad samotný je na začátku 15 . století písemnými prameny poprvé výslovně zmíněn jako „castrum in Wrtba“. Jedná se o zápis, jímž Sezema z Vrtby v roce 1405 daroval krašovickému kostelu lán polí ve vsi Krašovice výměnou za každoroční bohoslužbu za duše jeho potomků a předků konanou ve zdejším kostele. Zároveň týmž zápisem zbavil krašovického faráře i jeho nástupce každoroční povinnosti sloužit jednu mši na hradě Vrtba (LE V, 665). ${ }^{5}$ Lze tedy vyvozovat, že na hradě byl prostor vhodný ke slavení liturgie, nejspíše hradní kaple, která v prvním století existence hradu minimálně jednou ročně ožívala celebrováním bohoslužby vedené plebánem z Krašovic. „Sezema de Wrtba“ je pak uváděn ještě v roce 1406 v souvislosti s Habartem z Klenovic, což by mohlo naznačovat vazbu k tomuto rodu či rodové větvi, jak bude zmíněno ještě dále (DD VII, 149).

V době husitských válek náležel hrad Janu Štěpánovci z Vrtby. Ten v roce 1426 uzavřel s dalšími pány plzeňského kraje dohodu o vzájemné podpoře v boji proti husitům (AČ 3,259$)$. V. Kočka z tohoto ujednání vyvozuje, že vrtbovské statky musely být od husitů ničeny a patrně i hrad dobýván (Kočka 1932, 124). Žádné přímé doklady o tom ale k dispozici nejsou. ${ }^{6}$ Jan Štěpánovec z Vrtby patřil ve druhé čtvrtině 15 . století k předním šlechticům českého království, roku 1432 se měl zúčastnit poselstva do Basileje k dojednání husitských kompaktát.?

Z roku 1462 se dochovala další z nemnoha informací o části vrtbovského panství. Bratr Jana Štěpánovce, v prameni jmenovaný jako „Hroznota z Vrtba seděním tudiež“, tehdy koupil od Jana ze Žilova zápisný list na vsi Horní Břízu a Újezd (dnes zaniklá ves jihozápadně od Kaznějova), spolu s Dubským mlýnem (nedaleko Ledec), loukou nad tím mlýnem a krčmou v Ledcích (AČ 7, 662). ${ }^{8}$ Nicméně tento majetek při vrtebském hradě zůstal patrně jen krátce. ${ }^{9}$

Z roku 1467 jsou dochovány dva dopisy adresované Sezemovi z Vrtby, patrně dalšímu z bratrů Jana Štěpánovce. Děkan pražské kapituly Hilarius Litoměřický, který v té době pobýval v Plzni, v nich Sezemu naléhavě nabádá, aby dodržoval vůli papeže a odmítl poslušnost králi Jiřímu z Poděbrad. Zároveň aby „kněze faráře svého“ nenutil sloužit mše (AČ 6, 124-125), patrně $\mathrm{v}$ souvislosti s interdiktem uvaleným nad stoupenci krále. ${ }^{10} \mathrm{Zda}$ se ale tyto dopisy týkají př́mo vrtbovského panství a jaký „Sezemův kněz“ je míněn, není zřejmé. ${ }^{11}$ Že by na Vrtbě byl hradní kaplan, je značně nepravděpodobné.

Sezema Štěpánovec zemřel asi v roce 1477 (Kočka 1932, 125; Jánský 2009, 499). Posledním Štěpánovcem byl zřejmě Jan Hroznata, syn některého z výše uvedených bratrů. Za jeho nezletilosti vládl na Vrtbě v letech 1484-1488 Jan Habart ze Strochovic, patrně jako poručník. ${ }^{12}$ Jan Hroznata se po dosažení dospělosti psal roku 1490 na Zalužanech (u Orlíku) a roku 1499 na Orlíku, kde působil jako poručník nezletilých dětí z prríbuzenské př́ízně své manželky Elišky ze Svojšína. ${ }^{13}$ Ta v roce 1501 koupila na Starém Městě v Praze dům U jednorožce (dnes již zaniklá stavba proti kostelu sv. Mikuláše) a následně se vzdala vlastnických práv ve prospěch „Johanni Hroznate z Vrtby“", manžela svého (Teige 1915, 195). ${ }^{14}$ Nicméně zápis z roku 1510 dokládá, že Štěpánovci se v Praze patrně příliš nedařilo. Jan Hroznata „z Wrtba“ dům U jednorožce zastavil

5 Jako svědek zápisu je uveden Sezema Štěpánovec rezidencí na Nekmíři a Sezema, syn téhož, patroni řečeného kostela (LE V, 665). Nelze tedy nesouhlasit s povzdechem A. Sedláčka, že „,nastalo okolo $r .1370$ rozplození rodu tohoto takové, že jest nemožná věc vývod jeho rádné sestaviti“" (Sedláček 2000, XIII, 124).

6 Zánik v důsledku husitských válek je předpokládán u vsi Štěpánovice v bezprostřední blízkosti hradu. K. Foud a T. Karel uváději, že k roku 1427 je tato ves označována jako pustina (Foud-Karel 1993, 39), a to s odkazem na práci F. Macháčka, která však uvedené datum nezmiňuje (srov. Macháček 1929, 29-56).

7 Srov. více zmínek např. v Dějinách F. Palackého. Jan Štěpánovec z Vrtby mj. držel od r. 1437 i hrad Valdek a město Př́ibram (Kočka 1932, 124; Jánský 2009, 499), v r. 1472 vykonával funkci přísedícího komorního soudu (Jánský 2009, 187).

8 Jednalo se o majetek patřící plaskému klášteru, který však král Zikmund v roce 1421 zapsal pánům ze Žilova za pomoc při obraně hradu Karlštejna (k tomu viz AČ 2, 454; srov. také Kočka 1932, 139).

9 Např. ves (Horní) Bříza byla spolu s dalším zástavním zbožím plaského kláštera již před rokem 1484 v rukou Burjana z Gutštejna, který ji $\mathrm{v}$ tomto roce prodal Benešovi z Kolovrat sezením na Libštejně (AČ 8, 494n)

10 „Srozuměl sem, kterak kněze faráře swého chcete k tomu připrawiti mocí, aby slúžil, a nebo jej wyhnati.“ (AČ 6, 124).

11 Sezema držel také Hořovice (Kočka 1932, 125; Jánský 2009, 105, 499). Krašovická fara v období husitských válek zanikla a filiální kostel byl spravován z Bělé, nad níž v té době vykonávali podací právo páni z Gutštejna (Podlaha 1909, 31).

12 J. Jánský připouští, že mohl patřit k jiné větvi Hroznatovců (Jánský 2009, 188). V r. 1484 je „Jan Habart z Strochovic a na Vrtbě“ uveden jako svědek na listině řešíci spor města Plzně s Václavem Točníkem z Křimic (Listár̆ II, 230).

13 Na Orlíku byl poručníkem nedospělých dětí Jaroslava Zmrzlíka ze Svojšína na Orlíku a Kostelci (Jánský 2009, 188).

14 J. Jánský a V. Kočka uvádějí rok 1500, ovšem bez odkazu na pramen (Jánský 2009, 188; Kočka 1932, 125). 
věřiteli a následně o něj také přrišel (Teige 1915, 195). Ve stejné době, tedy nejspíš na konci první dekády 16. století, je prodán rovněž hrad Vrtba. ${ }^{15}$ Po téměř dvou staletích nepřetržité držby tak páni z Vrtby ztrácejí své nominátní sídlo, které přechází do majetku pánů z Rabštejna. ${ }^{16}$ Zánikem štěpánovské linie však rod Vrtbů neskončil; naopak jeho vrcholná epocha nastala o dvě století později, v pobělohorském období.

Rabštejnské držení Vrtby je poprvé doloženo k roku 1511, kdy je uvedena „Anna z Rabštejna a na Vrtbě “ jako věřitelka dluhu Zdeňka Lva z Rožmitálu (NA, ČG - GL). V písemných pramenech ji pak nalézáme ještě k roku 1525 (AČ 33, 345, 397). Vrtebské panství však náleželo Anninu bratrovi Janu z Rabštejna, který sídlil na Hostouni (Kočka 1932, 125). Začátkem roku 1538 Jan celé panství prodal Šebestiánu Markvartovi z Hrádku na Trpístech a Nekmíři.

O prodeji a jeho rozsahu se dozvídáme ze zápisu vloženého do desek zemských obnovovaných v roce 1542 po požáru: „Václav a Vojtěch bratři Hostounští z Rabštejna pravili, že dědictví někdy Jana otce jejich, Vrtbu zámek, dvůr poplužni s poplužim a druhý dvưr pustý řečený Štèpánovský, Lhotku, Mostice, Hubenov vesnice celé a dvory kmetcís poli, dédinami, lukami, lesy, potoky, rybniky, kurmi, vajci, robotami i se všim s panstvím, to vše, což jest tu nadepsaný někdy otec jich sám měl a držel a nížepsanému Šebestiánovi Markvartovi prve pred shořením desk (...) léta XXXVIII. ve čtvrtek po Novým létě ve dcky zemské kladl (...) zase dědicové nadepsaného Jana ve dcky zemské vložili a prodali Šebestiánovi Markvartovi z Hrádku, purkrabi Karlštejn-

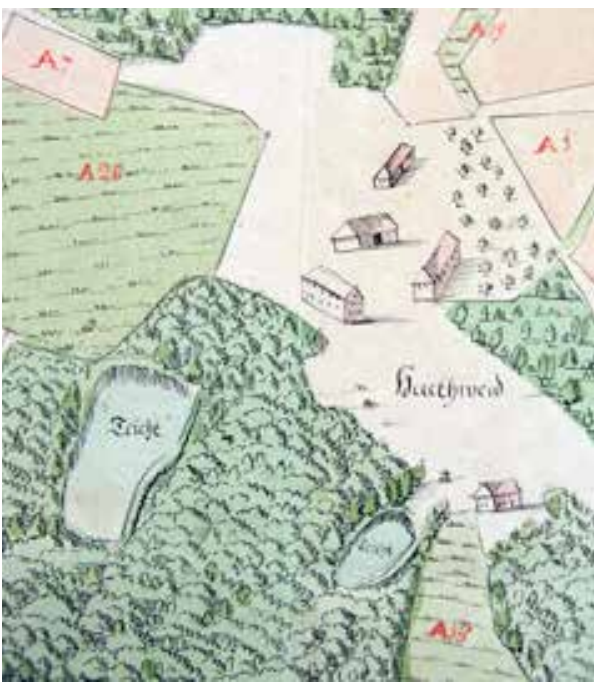

Obr. 2. Plán dvoru Vrtba od F. X. Preitsche z roku 1755, Národní archiv, Mapová sbírka II.

Abb. 2. Planskizze des Wirtschaftshofes von Vrtba von F. X. Preitsch aus dem Jahr 1755, Nationalarchiv, Kartensammlung II. skýmu, za pưl třinácta sta kop gr. pr. č. zaplacených postúpili“ (DZ I/1, 250).

Citovaná podrobná zpráva o vrtebském panství je však současně jakousi „labutí písní“ zdejšího hradu. Nový majitel Šebestián Markvart z Hrádku v roce 1555 přikoupil blízké panství Bělá, kde se trvale usadil, a zdejší hrad přestavěl na rezidenční zámek. Hrad Vrtba zůstal již natrvalo neobydlený, a tedy i neudržovaný. O sto let později, v odhadu bělského panství z roku 1659, je podrobně popsán jen hospodářský dvůr Vrtba s pustým rybníkem, hrad již zmíněn není (Kočka 1932, 125-126). Pro odhadní komisaře tedy neměl cenu už ani jako ruina. $O$ další století později byl - opět v souvislosti s odhadem panství - vyhotoven nejstarší plán vrtebského dvora a přilehlých pozemků (Kodera 2007, 103). I na tomto plánu z roku 1755 však hrad již není ani naznačen (obr. 2). O něco mladší I. vojenské mapování (1764-1768) kromě dvora zachycuje pouze terénní homoli v místě hradu a pod ní pozůstatek soustavy rybníků. ${ }^{17}$

\section{Dějiny bádání}

Hrad se objevuje v souhrnných pracích Augusta Sedláčka (2000, XIII, 124-125) nebo Georga Schmidta $(1928,34-40)$. Převážně na historii se zaměřil regionální historik Václav Kočka, jenž shromáždil velkou část archivních pramenů vztahujících se k tomuto hradu (Kočka

15 Pokud je Hroznata totožný s panem „Hruozou“ uvedeným mezi gutštejnskými pány k r. 1505 v souvislosti s tzv. loketskou vojnou proti Šlikům, pak vypravil do pole pouze dva pěší muže, což svědčí o jeho nevalných ekonomických poměrech (Jánský 2009, 188; AČ 6, 317).

16 Jan Hroznata je v letech 1509-1512 uváděn na Podviní (u Litoměřic) a r. 1522 v Polné (Jánský 2009, 188).

17 I. vojenské mapování - josefské; dostupné z: http://oldmaps.geolab.cz/, cit. 31. 12. 2018. 
1932, 123-126). Z místních badatelů můžeme zmínit Václava Širokého, který se Vrtbě věnoval v několika svých pracích (např. Široký 1930 nebo 1936), případně popularizační kompilaci Kateřiny Nové (2004/2005).

Až do zde prezentovaného průzkumu pojednali o této lokalitě nejobsáhleji Jan Anderle a Josef Miler, kteří rovněž ve svém článku publikovali plán hradu pořízený metodou protínání na stolku (Anderle-Miler 1985, 112-119). Na základě tohoto zaměření se pokusil Ladislav Svoboda o typologické zařazení hradu mezi tzv. hrady s pláštovou zdí (Svoboda 1995, 355-388). Vzhledem ke stavu lokality pro to však neexistují žádné relevantní opory.

Nejnovější povrchový průzkum proběhl v letech 2010 a 2011 a byl součástí bakalářské práce jednoho z autorů (Hobl 2011, 35-54). V průběhu tohoto průzkumu vzniklo mj. i nové zaměření totální stanicí, během něhož bylo naměřeno celkem 8567 podrobných bodů (obr. 3). Nové zaměření ukazuje, že předchozí plán (Anderle-Miler 1985) je velmi přesný a kvalitní, byt' obsahuje drobnou měřičskou chybu v jižní části areálu. Ta spočívá $\mathrm{v}$ zakreslení nepřesných úhlů $\mathrm{v}$ důsledku použité měřičské metody $\mathrm{v}$ terénu s velkým převýšením mezi hradním jádrem, příkopem a vnějším opevněním (obr. 4).

Pro úplnost je rovněž třeba zmínit, že na základě umístění lokality v krajině a nálezu keramického zlomku se slámovaným povrchem (učiněného jedním z autorů v roce 1990) je místo uváděno jako potenciální výšinné sídliště chámské kultury (John 2010, 103).

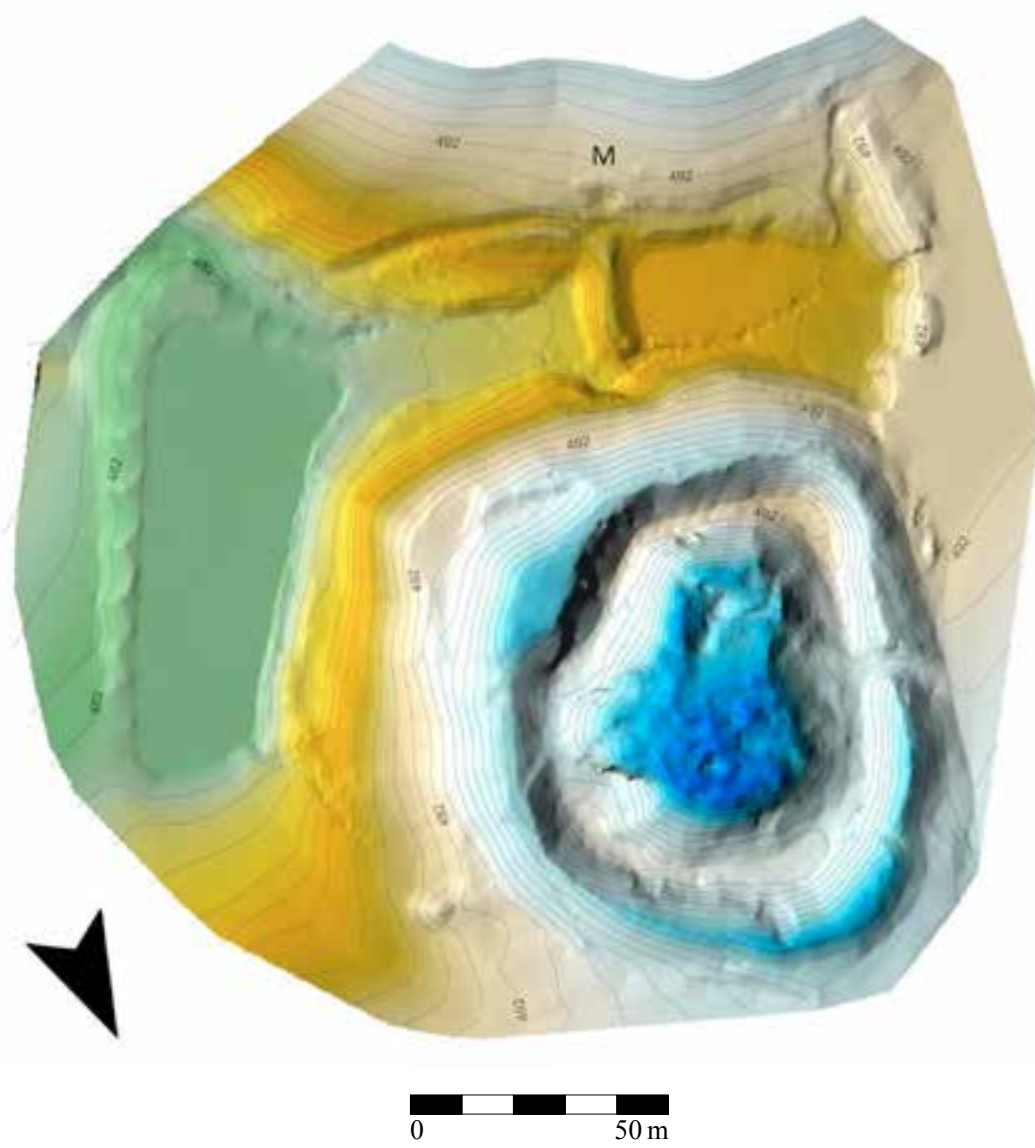

Obr. 3. Plán lokality 3D s vyznačením vrstevnic. M - pozice reliktů mlýna.

Abb. 3. 3D-Plan der Fundstelle mit Höhenschichtlinien. M - Lage der Mühlenrelikte. 


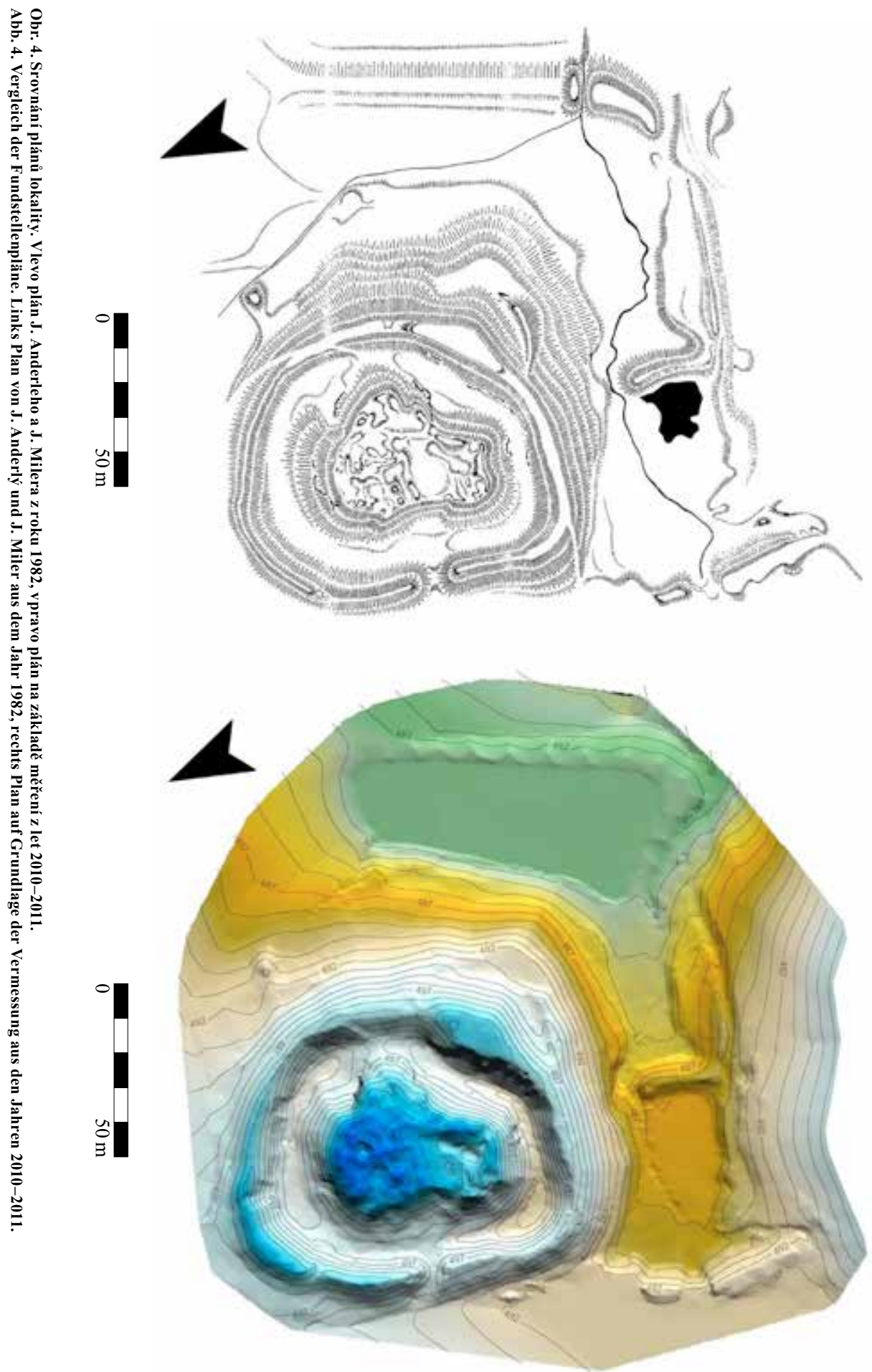




\section{Popis lokality a současný stav}

Hrad byl jednodílné dispozice. Hradní jádro obklopoval prŕíkop, před nímž se ještě nacházelo mohutné vnější opevnění. Tato fortifikace má nejednotnou formu. Na východní a jihovýchodní straně je podstatně širší než na straně západní. Je to způsobeno tím, že západní val byl zcela uměle nasypán. Násep je zde užší a koruna tohoto úseku opevnění je od ostatních částí oddělena i výškově (tato skutečnost je dobře patrná na modelu - obr. 3). Pravděpodobně někdy $\mathrm{v}$ období novověku byl v tomto nejužším místě vytvořen průraz pro odvoz stavebního materiálu z likvidovaného hradu.

Většina obvodové fortifikace však vznikla rozdělením původního morfologického útvaru uměle vyhloubeným př́kopem. Nicméně i v těchto částech je opevnění zčásti dosypáno, otázkou zůstává, do jaké míry. Na několika místech je ve svazích příkopu viditelné odtesané skalní podloží v hloubce zhruba 2-2,5 m pod korunou zemního opevnění. Samotná koruna je po většině svého obvodu široká $1,5-2 \mathrm{~m}$. Pouze na východní straně dosahuje šířky asi $4 \mathrm{~m}$. Toto rozššřnení navazuje na původní př́ístupovou komunikaci, která stoupala od severu po severovýchodním úbočí a byla zakončena vyvýšenou plošinou. Právě z ní můžeme předpokládat přístup do hradního jádra pomocí mostu, nejspíše dřevěného. Na vnějším svahu pod touto platformou se nachází další plošina, na jejíž jižní straně je pozůstatek drobného náspu. Jaký byl její účel, není možné jednoznačně určit. Vzhledem k umístění je však pravděpodobné, že se jedná o pozůstatek fortifikace, která mohla zajištovat vstupní plošinu, resp. vstup do vnitřního hradu.

Příkop oddělující hradní jádro a obvodové opevnění má impozantní rozměry. Jeho šířka se pohybuje v rozmezí od $18 \mathrm{~m}$ do $25 \mathrm{~m}$, převážně činí kolem $20 \mathrm{~m}$. Hloubka dosahuje až $8 \mathrm{~m}$.

Samotný pahorek hradního jádra má v podstatě tvar nepravidelného pětiúhelníku o rozměrech $45 \mathrm{~m}$ v ose sever-jih a $40 \mathrm{~m}$ (v nejširším místě), resp. $19 \mathrm{~m}$ (v nejužším místě) v orientaci východ-západ. Jeho celková rozloha je tedy pouze 0,103 ha. Vnitřní plochu narušuje mnoho konkávních i konvexních objektů nejrůznějších tvarů a velikostí. Jejich rozmístění činí situaci značně nepřehlednou. Tyto objekty můžeme spojit $\mathrm{s}$ rozebíráním hradu na stavební kámen v období novověku. Dvě nejvýraznější narušení lze určit blíže. První z nich je umístěno v jihovýchodní části a má podlouhle oválný tvar (o rozměrech zhruba $13 \times 6 \mathrm{~m} \mathrm{~s} \mathrm{hloubkou} \mathrm{od} \mathrm{1,4}$ do $1,8 \mathrm{~m}$ ). Vznik toho útvaru můžeme spojit s pokusem o zřízení krytu ve 40. letech 20. století (Anderle-Miler 1985, 212). Druhé výrazné zahloubení téměř kruhového tvaru se nachází v severní části. Průměr této jámy je ca $5 \mathrm{~m}$, hloubka asi $2 \mathrm{~m}$. S velkou pravděpodobností se jedná o nelegální výkop nejspíše z 80 . let 20 . století. V tomto narušení se nacházel pravoúhlý styk dvou zdí (Anderle-Miler 1985, 212). Na počátku 90. let byl tento výkop ještě prohlouben. Podle měřeného náčrtu jednoho z autorů (P. Kodera, 13. 10. 1991) dosáhlo prohloubení až $3,2 \mathrm{~m}$. V této době již pravoúhlý styk nebyl patrný. Zajímavé však je, že v hloubce $2,8 \mathrm{~m}$ od povrchu se nacházel odskok zdi, se kterým souvisela trámová kapsa. Tento detail by mohl naznačovat, že pod současným povrchem je zachováno větší množství zděných konstrukcí. ${ }^{18} \mathrm{~V}$ současné době v tomto narušení ovšem žádné zděné konstrukce viditelné nejsou. Díra byla částečně zasypána a pouze $\mathrm{v}$ jednom z ,profilü“ je patrná neurovnaná vrstva kamenů.

Další zbytky zdiva lze nalézt i v jiných drobnějších narušeních. Většinou se jedná o malé amorfní pozůstatky zdí bez líce. Skrovné, nicméně dobře patrné zbytky zdiva se nacházejí na hraně př́íkopu v jihovýchodní a jihozápadní části jádra. Severovýchodní svah jádra nese známky po lámání kamene. Současný stav tak zcela znemožňuje jakkoliv interpretovat původní podobu hradu. Ačkoliv z písemných pramenů vyplývá, že na hradě byla kaple (viz výše), stav a rozsah zachovaných kamenných konstrukcí by mohl odhalit pouze archeologický výzkum. Ten by rovněž jistě napomohl k ujasnění celkové podoby hradu.

$18 \mathrm{~S}$ tím, že by se pod povrchem mohly nacházet další zbytky zděných konstrukcí, koresponduje i průzkum z 80 . let. Tehdy autoři konstatovali, že základová spára se nachází poměrně hluboko ve svahu příkopu (Anderle-Miler 1985, 112-113). Bohužel tato situace je dnes zakryta spadlým kmenem stromu, takže není možné ji ověřit. 


\section{Hospodářské zázemí hradu}

Hospodářské zázemí vrcholně středověkého hradu můžeme rozdělit na bližší a vzdálenější. V pojetí článku jsou za bližší považovány objekty a provozy, které se nacházely v bezprostřední blízkosti hradu a zajišstovaly jeho každodenní provoz. Do vzdálenějšího zázemí pak patří vsi, které tvořily panství, z něhož prostřednictvím feudální renty plynuly majitelům hradu zisky.

\section{Bližší hospodářské zázemí}

V bezprostřední blízkosti hradu se žádná vesnice nenacházela, ${ }^{19}$ nicméně nějaké hospodářské zázemí, jež by zajištovalo běžný provoz, zde předpokládat musíme. Hospodářský dvůr, přesněji „dvưr poplužní s poplužim“, se objevuje v soupisu panství při jeho prodeji z roku 1538 (DZ I/1, 250; viz výše). Dodnes ze dvora existuje několik budov barokního stáří (na stodole je osazen znak plaského opata Fortunáta Hartmana z roku 1761). ${ }^{20}$ Velmi pravděpodobně tento barokní dvůr měl svého středověkého předchůdce. Ten vůči hradu mohl suplovat funkci, kterou na jiných sídlech plnilo předhradí. Této interpretaci nasvědčuje i poloha dvora pod př́stupovou cestou do hradního jádra, resp. na obvodové opevnění. Nic nesvědčí o tom, že prostor dvora byl někdy opevněn. Ekonomickou jednotkou, kterou mělo smysl využívat i dále upravovat, zůstal dvůr i po zániku hradu.

Zajímavá situace se nalézá na jižní a východní straně před obvodovým opevněním. Nacházela se zde soustava tří rybníků, které využívaly vodu nedaleko pramenícího Brodského potoka (obr. 5). Nejníže položený rybník kaskády se rozkládal na východní, částečně jižní straně areálu. Jeho hráz je nejdelší, byla ale z části upravena, když byl rybník v roce 2006 obnoven. Tato úprava jeho historickou podobu poněkud změnila, nicméně i díky zaměření z roku 1982 (Anderle-Miler 1985, obr. 4) víme, že původní hráz na východní straně byla v podstatě jen doplněna. Přestože se na ni na jihu napojil nový násep, je dnešní rybník o něco menší než ten původní. Proti proudu potoka lze identifikovat další dvě hráze, které předělují prostor mezi vnějším opevněním hradu a blízkým kopcem. Prostřední hráz kaskády se nachází zhruba ve středu tohoto sedla a byla stržena povodní někdy na počátku 20. století (Anderle-Miler 1985, 117). Dá se předpokládat, že tento prostřední rybník měl funkci jakési přepouštěcí nádrže. Západní, v kaskádě nejvyšší, hráz byla vybudována na horním okraji výše zmíněného sedla. Patrná jsou poškození na několika místech, která můžeme spojit s úpravami terénu při výstavbě betonové nádrže v prostoru původního rybníka (Anderle-Miler 1985, 117). Zde se nepochybně sbírala hlavní zásoba vody pro celou kaskádu. Kromě hospodářské funkce měla rybniční soustava také funkci fortifikační. Rybníky hrad obklopovaly téměř ze tř́i stran, které byly nejvíce ohroženy blízkými kopci. Zejména východní, nejníže položený rybník dokládá, že obranná funkce zde byla primární. Pro provoz mlýna význam neměl a jeho dlouhá, více než 100 metrová hráz by z jiného než fortifikačního hlediska byla neopodstatněná. Složitá je otázka, zda hladina tohoto, v kaskádě posledního, rybníka dosahovala až k vyšší (prostřední) hrázi. Podle současné konfigurace terénu se zdá, že nikoliv. Současná koruna východní hráze je o 2,4 m níže než úroveň terénu pod prostřední hrází. Zda byla situace ve středověku jiná, není možné povrchovým průzkumem stanovit. V každém případě zde lze předpokládat silně podmáčený terén (ostatně stejně jako dnes), který by fortifikační úlohu mohl splňovat dostatečně.

Prakticky celou jižní stranu výše popsané rybniční soustavy lemují další terénní relikty. Ty začínají pod západní, v kaskádě nejvyšší, hrází a pokračují až ke hrázi východní. Dle všeho se jedná o pozůstatky hospodářského provozu, který využíval vodu. Hlavní část tohoto provozu se nacházela na úrovni prostřední hráze. Dnes je na tomto místě patrný lehce zahloubený objekt pravidelného půdorysu o rozměrech $6,5 \times 7,5 \mathrm{~m}$. Pravděpodobně se jednalo o mlýn; menší rozměry nejsou u hradních mlýnů neobvyklé (Štěpán 2002, 7). Mezi tímto objektem a západní hrází se nachází úzká vyrovnaná plošina, která je dnes dlouhá $40 \mathrm{~m}$ s převýšením pouhých

19 Současná osada Vrtbo vznikla až po roce 1848 (Kočka 1932, 126).

20 Plaský klášter koupil bělské panství spolu s vrtebským dvorem roku 1757 (srov. např. Rožmberský 1999a, 35). 


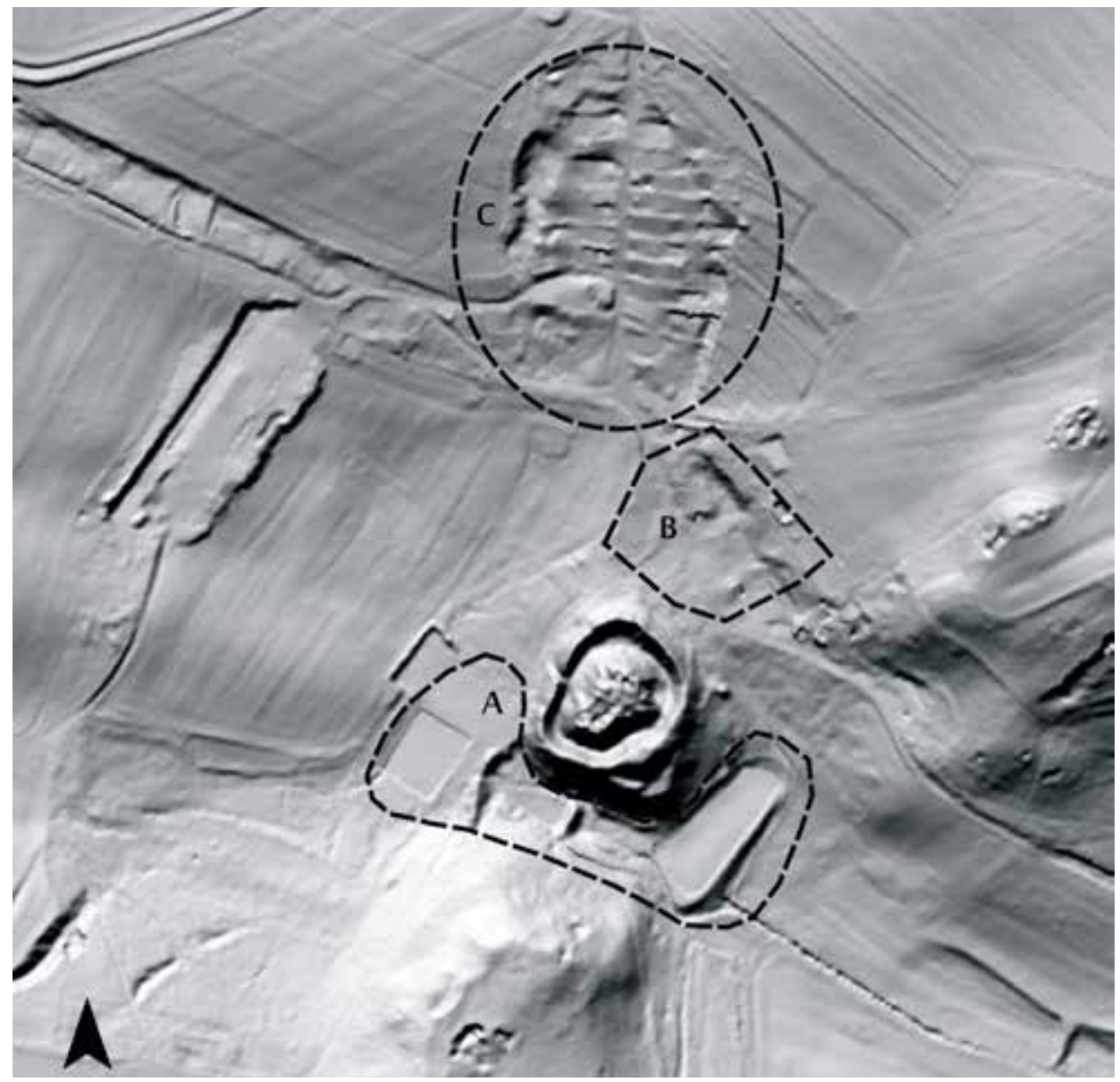

Obr. 5. Lidarový snímek lokality s vyznačením rybniční soustavy s mlýnem (A), prostorem hospodářského dvora (B) a vesnice vzniklé po roce 1848 (C).

Abb. 5. Lidar-Aufnahme der Fundstelle mit Kennzeichnung des Teichsystems mit Mühle (A), Bereich des Wirtschaftshofes (B) und einem nach 1848 entstandenen Dorf $(C)$.

$80 \mathrm{~cm}$. Jelikož takto malé převýšení nemohlo stačit na pohon vodního kola, stály na této plošině nejspíše dřevěné vantroky, jež musely mít dostatečný sklon. Spíše se proto jednalo o vodní kolo na horní vodu, které je efektivnější a vystačí i s menším množstvím vody. ${ }^{21}$ Od zmíněného objektu pokračovala voda dále k východu. Zde se již ovšem nejedná o plošinu, ale o $70 \mathrm{~cm}$ hluboké koryto, kdysi zaústěné do nejnižšího rybníka kaskády. Způsob napojení mlýnské sestavy na nejvyšší, západní rybník, který celý provoz napájel, dnes již bohužel není možné rozpoznat. Tato situace byla nejspíše setřena mladšími úpravami hráze. ${ }^{22} \mathrm{Kdy}$ mlýn vznikl, ani kdy zanikl, nelze jednoznačně určit.

Mlýny obecně náleží k častému vybavení hradů. Asi nejznámějším příkladem je hradní mlýn hradu Krašov (rovněž na severním Plzeňsku), který byl součástí jeho pozdně středověkého,

21 Za konzultace na téma vodních mlýnů děkujeme Mgr. Lucii Galusové, Ph.D.

22 Úpravy hrází jsou předpokládány na základě vojenských mapování, která ukazují, že některé z rybníků byly znovu využivány v období novověku. 
značně rozsáhlého předhradí. Rozměry tohoto mlýna byly asi $5 \times 4 \mathrm{~m}$, a jsou tedy s relikty dochovanými na Vrtbě velikostně srovnatelné (srov. Galusová 2011, 115).

\section{Vzdálenější hospodářské zázemí}

Základ hroznatovských panství tvořily patrně majetky předka rozrodu Hroznatovců Jetřicha z Krašovic, které si rodové větve mezi sebou dělily. ${ }^{23}$ Změny v držení hradu Vrtba jsou stručně zmíněny v části věnované historii hradu; v následujících odstavcích bude podrobněji pojednán rozsah panství v předhusitském období, především na konci 70. let 14. století.

Klíčovým pramenem pro poznání majetkové držby na Plzeňsku v této době je berní rejstř́k Plzeňského kraje z roku 1379. Jak je uvedeno výše, můžeme za majitele vrtebského panství dle tohoto pramene považovat bratry Petra a Sezemu. Jejich dominium tehdy tvořily vesnice Košetice, Klenovice, Lhota (Lhotka) a Popovice (Bernaregister, 26). ${ }^{24}$ Berní ve výši 11 hřiven (marek) se řadili k nadprůměrným plátcům. Vesnice jsou od hradu v různé vzdálenosti (Košetice $-7,5 \mathrm{~km}$, Klenovice $-5,5 \mathrm{~km}$, Lhotka $-1 \mathrm{~km}$, Popovice $-6,5 \mathrm{~km})^{25}$ a kompaktní doménu netvoří. Některé z nich naopak mají mnohem blíže k jiným hradům (Popovice i Klenovice zhruba $1,5 \mathrm{~km}$ k Podmoklům, Košetice necelý $1,5 \mathrm{~km}$ k Frumštejnu) a mezi nimi a Vrtbou se nacházela i další panská sídla (obr. 6). ${ }^{26}$

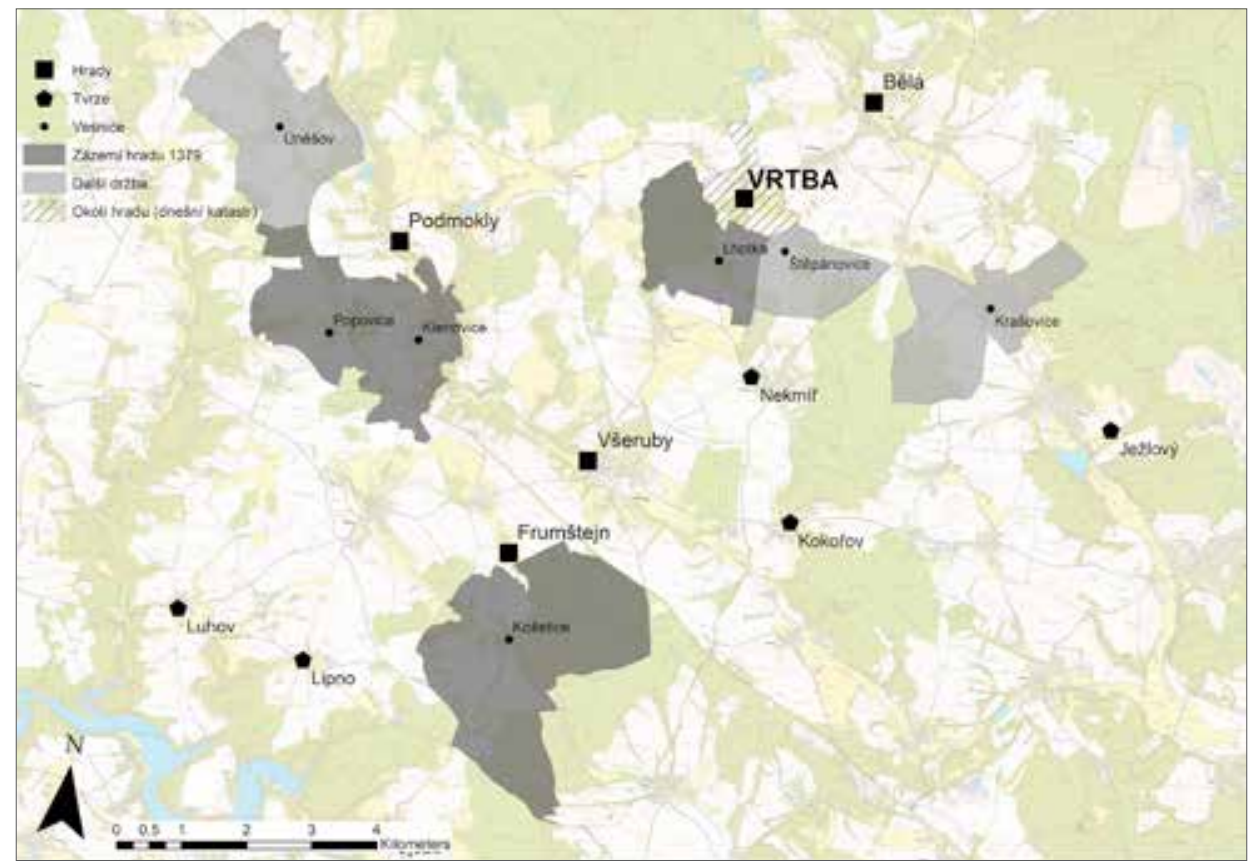

Obr. 6. Zázemí hradu a další majetky pánů z Vrtby k roku 1379. Autor mapy L. Hobl.

Abb. 6. Hinterland der Burg und weitere Besitztümer der Herren von Vrtba zum Jahr 1379. Karte erstellt von L. Hobl.

23 Přinejmenším zčásti byl majetek dědictvím po Hroznatovi Tepelském (nebo též z Ovence; † 1217), který měl v této oblasti některé ze svých statků. Jetřich z Krašovic byl potomkem jednoho z Hroznatových bratrů, pravděpodobně Sezemy (srov. Jánský 2009, 50-51).

24 „LXXX. Bona domini Sezeme: Kossetycz. Klenowycz, Lhota, Popowycz. Pactauit pro XI mar.“

25 Měřeno vzdušnou čarou, zaokrouhleno na $0,5 \mathrm{~km}$.

26 Všechny mapy jsou vytvořeny na základě současných katastrálních území, v některých případech byly upraveny na základě map stabilního katastru. Pokud se jednalo o zaniklé vsi, byl jejich územní rozsah určen na základě anomálii současného katastru, případně též pomístních jmen apod. Rozsah církevního majetku a majetku královských měst vychází studie Z. Hojdy a J. Peška (1979) s přihlédnutím k práci K. Nováčka (2010). 
V držení pánů z Vrtby možná byly i další vesnice zapsané v rejstř́iku, byt' k přímé výbavě hradu nutně nenáležely. Jejich rozpoznání poněkud ztěžuje velmi frekventovaný výskyt jména Sezema, jež je uváděno většinou bez predikátu. ${ }^{27}$ Se značnou mírou pravděpodobnosti tak můžeme k majetku pánů $\mathrm{z}$ Vrtby přiřadit ves Úněšov, vzdálenou od hradu asi $7 \mathrm{~km}$. I ta je v berním rejstř́k u uvedena jako majetek blíže neurčeného Sezemy, již o 12 let později, roku 1391, ji však bratři Petr a Sezema ze Štěpánovic prodávají Buškovi z Klenovic (PDZ I, 541). ${ }^{28}$

Rovněž vesnice Krašovice, spojená s rozrodem Hroznatovců, je v registru uvedena jako majetek jakéhosi Petra (Bernaregister, 4). S ohledem na skutečnost, že Petr z Vrtby je k roku 1364 zmíněn jako patron zdejšího kostela (viz výše), jedná se patrně o tutéž osobu, která v době sepsání berního rejstř́ku spoluvlastnila i hrad Vrtba. Rovněž výše citovaná zpráva z roku 1405 o beneficiu pro krašovický kostel dokládá, že Vrtbové ves, nebo alespoň její část, drželi (LE V, 665). Krašovice jsou od hradu vzdáleny asi $4 \mathrm{~km} .{ }^{29}$

Ves Štěpánovice, která snad již v této době byla i sídlem štěpánovské větve pánů z Vrtby, $\mathrm{z}$ neznámého důvodu v berním registru chybí, byt nepochybně k majetku hradních pánů příslušela. ${ }^{30}$ Dnes již zaniklá vesnice se rozkládala jen necelý kilometr od hradu. ${ }^{31}$

Analýza berního rejstř́íku umožňuje zasadit vrtbovské dominium do struktury širšího regionu severního Plzeňska. V tomto prostoru měly větve rozrodu Hroznatovců, tj. páni z Bělé, Gutštejna, Frumštejna, Nekmíře a samozřejmě z Vrtby, dominantní postavení. Jak je patrné z přiložených map (obr. 7), majetky Vrtbů ani dalších větví netvoří uzavřené územní celky, nýbrž se vzájemně prolínají. ${ }^{32}$ Nicméně uzavřenou enklávu netvoří ani majetky celého rozrodu. Může to souviset s tím, že v době, kdy se rod začal politicky i ekonomicky vzmáhat, tj. ve druhé polovině 13. století, bylo území, na němž se jádro statků nacházelo, prakticky ze všech stran obklopeno majetky církevních institucí vzniklých již v průběhu 12. anebo na začátku 13. století. Na severovýchodě měl své statky cisterciácký klášter v Plasích, na severu komenda johanitů v Manětíně, k jihu a částečně k západu benediktinský klášter v Kladrubech a na severozápadě premonstrátský klášter v Teplé. Poslední jmenovaný byl založen několikrát zmiňovaným velmožem Hroznatou. Ten nadal klášter poměrně bohatými donacemi, které s majetky Hroznatovců bezprostředně sousedily. ${ }^{33}$ Přímo v centru sledovaného území vlastnil řadu vesnic již zmiňovaný kladrubský klášter, se kterým v průběhu 14. století jednotlivé hroznatovské větve majetky směňovaly (viz např. výše). Navíc na jihovýchodě i jihozápadě v průběhu 13. století vznikla dvě královská města - Plzeň a Stříbro. Z rozboru berního rejstř́iku ostatně vyplývá, že majetková roztř́ištěnost nebyla problémem pouze Hroznatovců. Ve sledované oblasti se nacházelo značné množství vlastníků, s nímž koresponduje i značné množství doložených feudálních sídel (pochopitelně ne každý vlastník vsi nebo její části měl svůj hrad nebo tvrz). Tato rozdrobenost v relativně

27 Kromě Sezemy z Vrby to byli přinejmenším Sezema z Bělé a Sezema z Podmokel. Jméno Sezema se však vyskytuje i u dalších míst v okolí (Radimovice, Čemíny ad.).

28 Tento převod ovšem mohl být pouze v rámci rodu. Někteři autoři se domnívají, že Bušek z Klenovic mohl být jedním ze synů Sezemy z Vrtby a bratrem Sezemy a Petra ze Štěpánovic (Sedláček 2000, XIII, 127; Kočka 1932, 124; Fridrich 1970, 222). - K roku 1395 je zmiňován Jan, sirotek po Buškovi z Vrtby (PDZ I, 556).

29 Z. Hojda a J. Pešek k majetku Sezemy z Vrtby připojují i část vsi Dražně. Ta byla však dle rejstříku rozdělena na čtvrtiny, přičemž jednu část vlastnil Sezema z Bělé a další Sezema, u něhož není predikát uveden, je však zapsán bezprostředně před popisem př́islušenství Vrtby (Hojda-Pešek 1979, 153).

30 Důvodem může být opomenutí (resp. nekompletnost pramene), anebo Štěpánovice byly po právní stránce dále vlastnictvím kladrubského kláštera. Z majetků všech klášterů se berně vybírala jiným způsobem, proto nejsou v rejstříku uvedeny (z obdobného důvodu předpokládá P. Rožmberský absenci Kaceřova a dalších vsí, které měl v držení Ctibor ze Švamberka, ale nejspíše dále byly formálně vlastnictvím plaského kláštera; srov. Rožmberský-Novobilský 2007, 8).

31 Ves tohoto jména je poprvé uvedena ve falzu z roku 1115 jako dar knížete Vladislava I. klášteru v Kladrubech (CDB I, 396$)$. K roku 1186 bylo toto nadání potvrzeno knížetem Bedřichem („Scepanovici“; CDB I, 427) a následně kolem roku 1239 papežem Řehořem IX. („Scepanouici“; RBM I, 455). Dle neověřené informace V. Kočky se k roku 1364 píše seděním na Štěpánovicích jeden z př́íslušníků pánů z Vrtby, a to Sezema zvaný Štěpánovec (Kočka 1932, 133 - bez udání zdroje). Nabytí této osady do majetku Vrtbů může souviset s majetkovými přesuny mezi kladrubským klášterem a tímto rodem, k nimž docházelo ve stejném období (směna vsi Kyjov a Malesice za Lubenec v r. 1364 - k tomu viz výše). Ves zanikla patrně v průběhu husitských válek (k povrchovému průzkumu této osady viz Foud-Karel 1993; srov. také Rožmberský 1993, 25-26).

32 Rozsah držby na mapách je vyjádřen jako minimální, zařazeny byly pouze vsi, u nichž je jejich držba nesporná, takže reálný rozsah mohl být větší. Zároveň zde nejsou prezentovány držby, které jsou vzdálené více než $20 \mathrm{~km}$ od sídla, po nichž se psal některý z příslušníků jednotlivých větví - např. držba částí vesnice ve Vysoké Libyni pány z Gutštejna (srov. Úlovec-Jánský 2000, 80).

33 Bohaté donace dal Hroznata též klášteru premonstrátek v Chotěšově, který založil společně se svou sestrou Vojslavou (srov. např. Janský 2009, 35, 47). Tento klášter se nachází jižněji od námi sledované oblasti. 


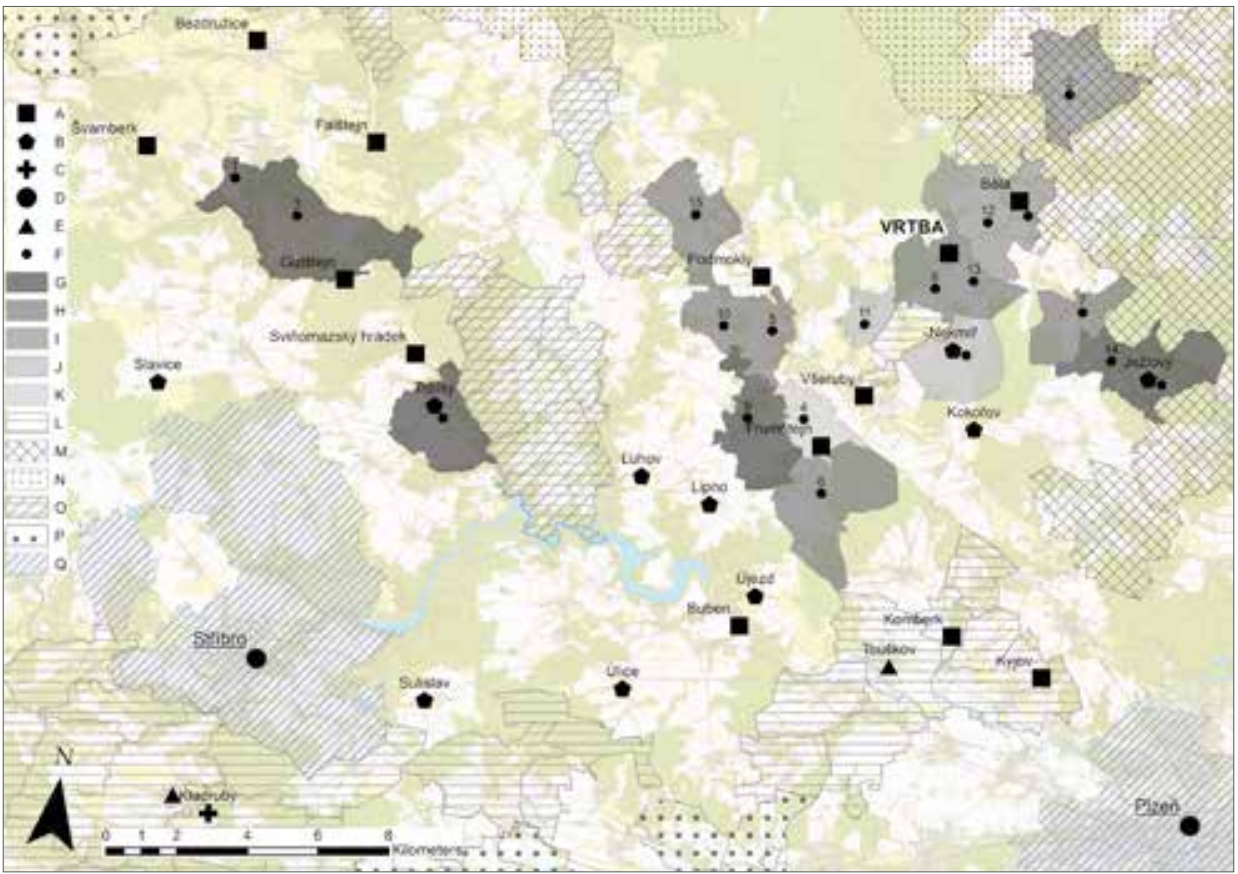

Obr. 7. Majetková držba jednotlivých větví Hroznatovců z roku 1379 v kontextu severního Plzeňska. A - hrady, B - tvrze, C - kláštery, D - královská města, E - poddanská města, F - vesnice v majetku hroznatovských větví (včetně částečné držby), G - držba pánů z Gutštejna, $\mathrm{H}$ - držba pánů z Vrtby, I - držba pánů z Bělé, J - držba pánů z Nekmíře, $K$ - držba pánů z Frumštejna, L - držba benediktinů z Kladrub, M - držba cisterciáků z Plas, N - držba johanitů z Manětína, O - držba premonstrátů z Teplé, $P$ - držba premonstrátek z Chotěšova, Q - zázemí královských měst. Vesnice v držení Hroznatovců: 1 - Břetislav, 2 - Dražeň, 3 - Hradiště (Okrouhlé), 4 - Hunčice, 5 - Klenovice, 6 - Košetice, 7 - Krašovice, 8 - Lhotka (Lhota), 9 - Líšt'any, 10 - Popovice, 11 - Slatina, 12 - Slavíkovice (zaniklá blíže nelokalizovaná), 13 - Štěpánovice (zaniklá), 14 Trnová, 15 - Úněšov. Vesnice Bělá, Ježlový (zaniklá blíže nelokalizovaná) a Trpísty jsou vyznačeny poblíž stejnojmenných panských sídel. Autor mapy L. Hobl.

Abb. 7. Besitztümer der einzelnen Familienzweige der Hroznatovei zum Jahr 1379 im Kontext der nördlichen Region Pilsen. A - Burgen, B - Festen, C - Klöster, D - Königsstädte, E - Untertanenstädte, F - Dörfer im Besitz der Familienzweige der Hroznatovci (einschließlich Teilbesitzungen), G - Besitzung der Herren von Guttenstein, $\mathbf{H}$ - Besitzung der Herren von Vrtba, I - Besitzung der Herren von Běla, J - Besitzung der Herren von Nekmíŕ, K - Besitzung der Herren von Frumstein, L - Besitzung der Benediktiner von Kladrau, $M$ - Besitzung der Zisterzienser von Plaß, N - Besitzung der Johanniter von Manetin, O - Besitzung der Prämonstratenser von Tepl, P - Besitzung der Prämonstratenser von Chotieschau, Q - Hinterland der Königsstätdte. Dörfer im Besitz der Hroznatovi: 1 - Břetislav, 2 - Dražeň, 3 - Hradiště (Okrouhlé), 4 - Hunčice, 5 - Klenovice, 6 - Košetice, 7 - Krašovice, 8 - Lhotka (Lhota), 9 - Líšt’any, 10 - Popovice, 11 - Slatina, 12 - Slavíkovice (nicht näher lokalisierte Wüstung), 13 - Štěpánovice (Wüstung), 14 - Trnová , 15 - Úněšov. Die Dörfer Bělá, Ježlový (nicht näher lokalisierte Wüstung) und Trpísty wurden in der Nähe der gleichnamigen Herrensitze eingezeichnet. Karte erstellt von L. Hobl.

uzavřeném prostoru jistě znesnadňovala vytvoření větších územních celků, jež v tomto období ovšem nebyly nutností. Další písemné prameny nám ukazují, že docházelo k poměrně značným a rychlým změnám majitelů jednotlivých vsí (srov. výše).

Do rozsahu panství v samém závěru existence hradu, tedy přibližně 150 let od sepsání uvedeného berního registru, nám dává nahlédnout výše citovaný zápis o prodeji Vrtby roku 1538 (DZ I/1, 250). Vyplývá z něho, že panství bylo prodáno jako celek. Všechny vesnice a dvory uvedené v zápisu, tedy Lhotka, Mostice, Hubenov, poplužní dvůr u hradu a pustý dvůr ve Štěpánovicích, jsou ve vzdálenosti do $2 \mathrm{~km}$ od hradu. Vytvářejí tak relativně malé, ale kompaktní panství (obr. 8), což v pozdním středověku a na počátku novověku byl již běžný jev i ekonomická potřeba. 


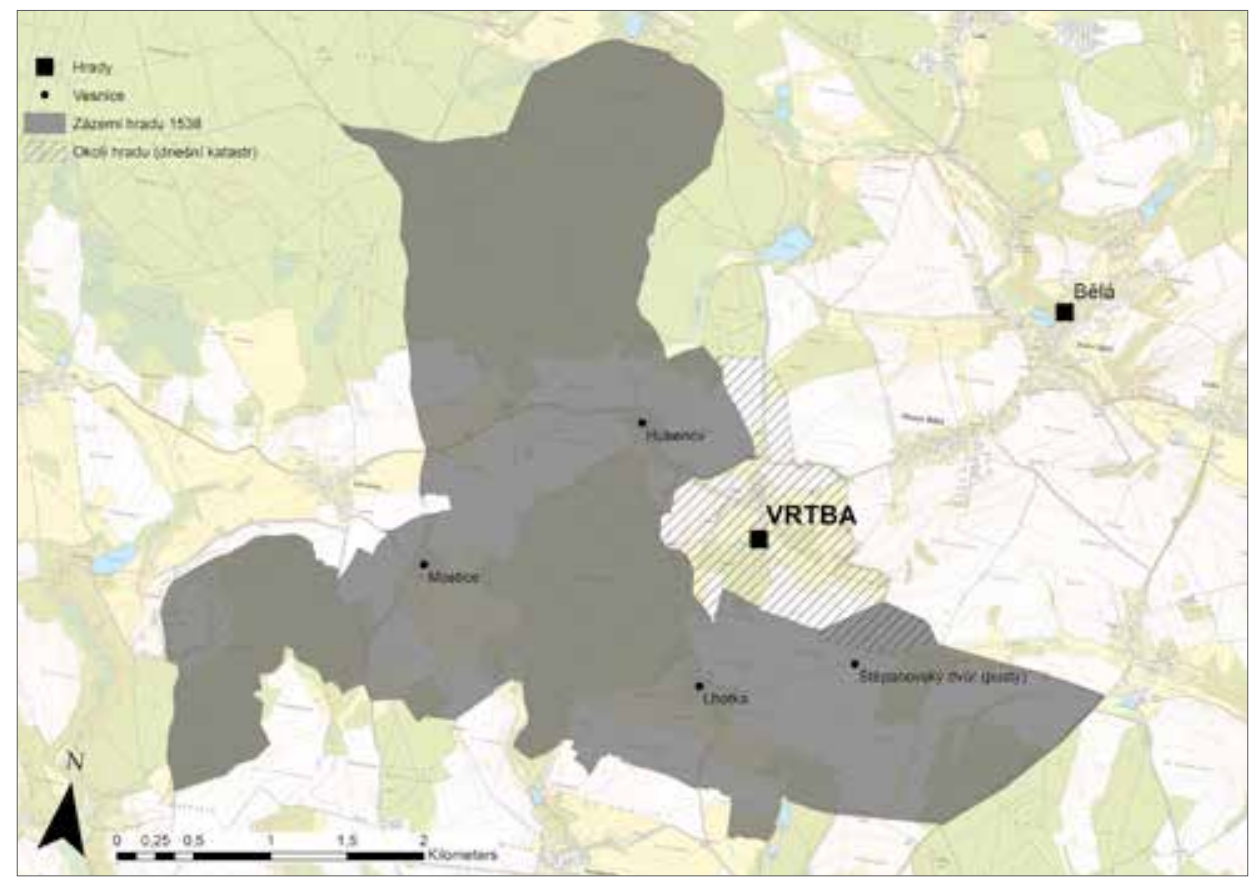

Obr. 8. Panství hradu Vrtba k roku 1538. Autor mapy L. Hobl.

Abb. 8. Herrschaft von Burg Vrtba zum Jahr 1538. Karte erstellt von L. Hobl.

\section{Zhodnocení movitých archeologických pramenů}

Většina hodnocených archeologických pramenů pochází z povrchového průzkumu J. Anderleho a J. Milera z 80. let 20. století. Nálezy jsou uloženy v Západočeském muzeu v Plzni. Jedná se o sběr z nelegálních výkopů a o nálezy získané od místních obyvatel (Anderle-Miler $1985,118)$. Menší část pak byla získána povrchovým sběrem jedním z autorů. Nicméně vypovídací hodnota takto získaných nálezů je ve vztahu k jejich poměrně malému množství značně omezena. ${ }^{34}$

Převážnou část souboru tvoří keramické fragmenty, včetně zajímavých zlomků komorových kachlů z čelních vyhřívacích stěn (dále jen ČVS). Kamnářská keramika byla proto hodnocena samostatně. Dále jsou zastoupeny zlomky stavební keramiky (části cihel a prejzů) a ojedinělé osteologické nálezy (nebyly hodnoceny) i jeden kovový artefakt.

\section{Kuchyňská a stolní keramika}

Kuchyňská a stolní keramika byla v souboru zastoupena celkově 114 zlomky. Nepatrně převažuje redukčně pálená keramika (66 zlomků), zatímco materiál oxidačně pálený byl zastoupen v menším množství (48 zlomků).

Ve fragmentech výrazně převažují atypické zlomky (79ks). Okrajů bylo v souboru celkem jedenáct s převahou různých variant ovalených okrajů. Dále byla zastoupena dna (13ks), na nichž lze nalézt stopy po odříznutí strunou $(8 \mathrm{ks})$ a po podsýpce $(2 \mathrm{ks})$; ve zbývajících tř̌ech

34 Nálezy jsou uloženy a evidovány v Západočeském muzeu v Plzni pod inventárními čísly HA19477-HA19479, HA25131, HA14370, HA23406-HA23412, HA23414-HA23423, HA25130. Za zpř́istupnění děkuji Mgr. Jiřímu Ornovi z uvedeného muzea. 
prŕpadech nebylo možné použitou technologii identifikovat. Přítomné jsou též dva zlomky páskovitých asymetrických uch a knoflík pokličky.

Celkem 14 fragmentů bylo zdobených. Nejpočetněji jsou zastoupeny ryté intervalové šroubovice ( $7 \mathrm{ks})$, dále radélková výzdoba (4ks) a vývalkovité šroubovice $(2 \mathrm{ks})$. V jednom prŕpadě se vyskytuje výzdoba s okrouhlými vpichy v pravidelných rozestupech doplněná rytou šroubovicí. Některé zlomky byly leštěné.
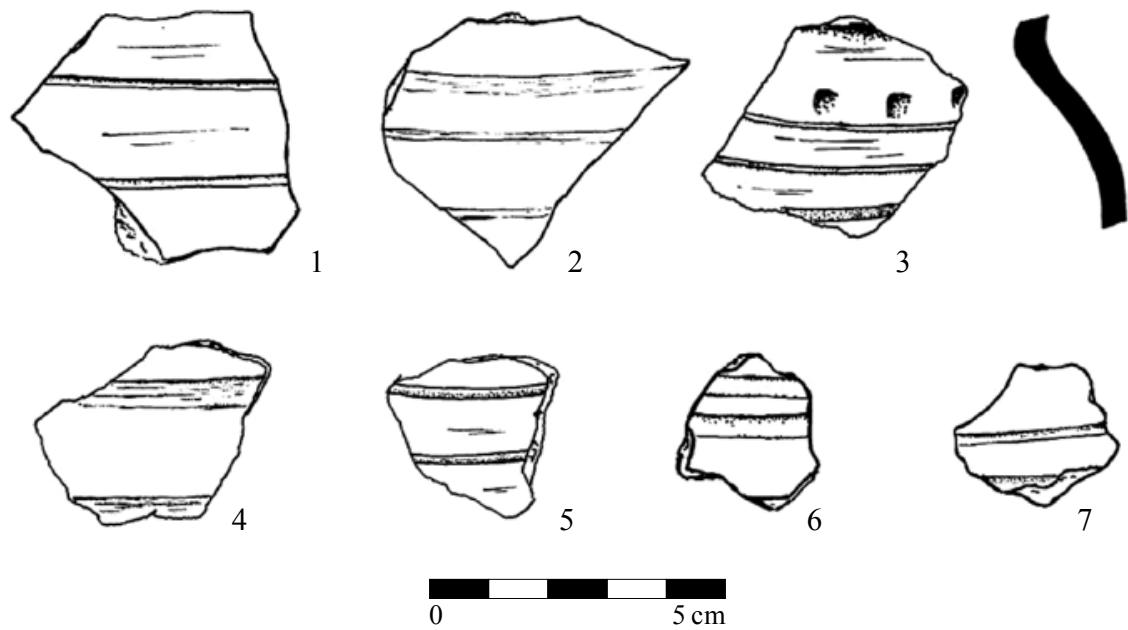

Obr. 9. Starší fáze kuchyňské a stolní keramiky. Kresba E. Ventrubová.

Abb. 9. Ältere Phase der Küchen- und Tafelkeramik. Zeichnung E. Ventrubová.
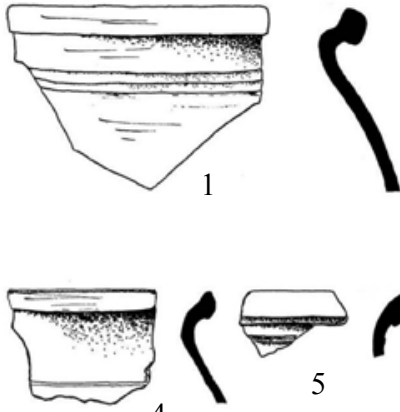

4
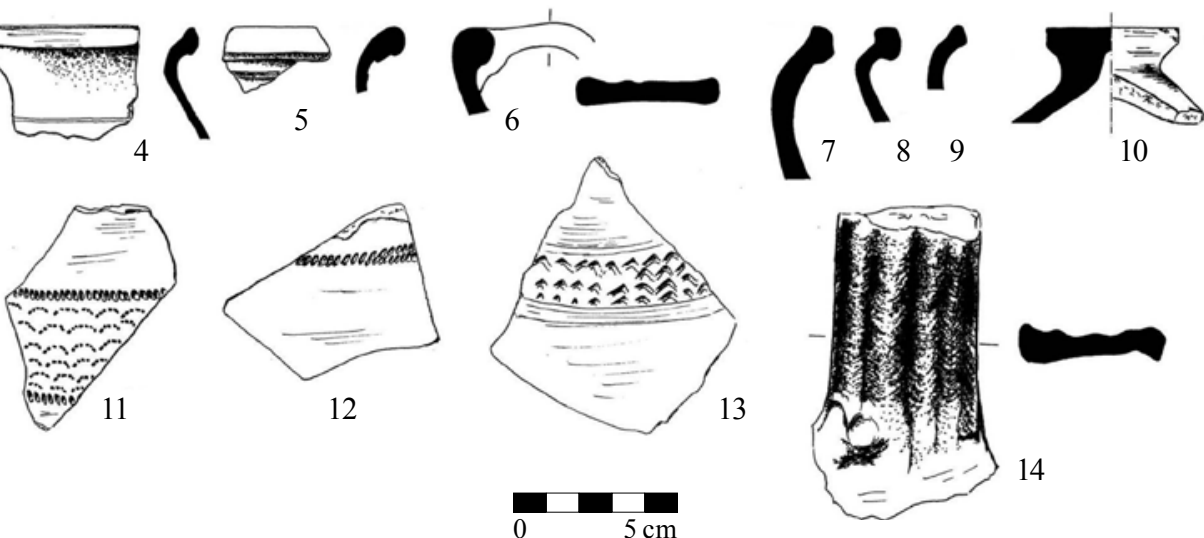

10

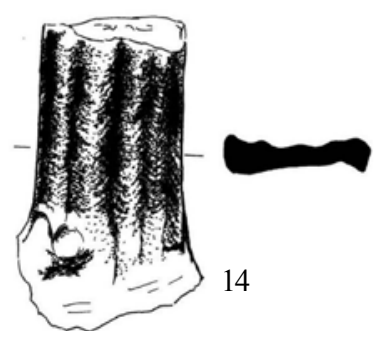

Obr. 10. Mladší fáze kuchyňské a stolní keramiky. Kresba E. Ventrubová.

Abb. 10. Jüngere Phase der Küchen- und Tafelkeramik. Zeichnung E. Ventrubová. 
Z keramických tvarů jsou nejvíce zastoupeny tvary hrncovité, nicméně střepový materiál neumožňuje jejich bližší poznání. Z dalších tvarů je možné rozpoznat kahan a pokličku.

Obecně lze vydělit ze souboru dvě skupiny, které se odlišují použitou technologií i výzdobou. V první (obr. 9) převažuje středně tvrdý oxidační výpal zdobený hlavně rytými a vývalkovitými šroubovicemi a rovněž sem můžeme zařadit zlomek s okrouhlými vpichy (obr. 9:3). Rámcově je možné chronologické zařazení od druhé poloviny 13. století až do poloviny 14. století. Druhá skupina (obr. 10) se vyznačuje tvrdým převážně redukčním výpalem. Výzdoba je zastoupená radélky a rytými liniemi (v jednom př́ípadě zdvojená). $K$ této skupině rovněž náleží různé varianty ovalených okrajů. Dataci lze pravděpodobně směřovat do druhé poloviny 14. a hlavně do 15. století. Jelikož středověká keramická produkce severního Plzeňska není dostatečně dobře poznána, mohou být obě skupiny datovány pouze na základě obecných znaků.

\section{Kamnářská keramika}

Kamnářská keramika je zastoupena celkem 81 zlomky. Ve fragmentech byly zjištěny morfologické části komorových kachlů, nádobkových kachlů s pravoúhlým ústím a kachlů výklenkových. Nejvíce zlomků náleži komorovým kachlům. Většina (41 ks) pocházela z čelních vyhřívacích stěn. Dále byly přítomny tři zlomky okrajů zadního vyhřívacího otvoru (obr. 11:5-6) a na dvou fragmentech pláště byly boční záchytné otvory. Střepy nádobkových kachlů s pravoúhlým ústím jsou zastoupeny v souboru celkem dvaadvacetkrát. Přítomny byly okraje (11 ks; obr. 11:1-4) a jeden fragment dna. Marginální je zastoupení výklenkových kachlů, jimž náleží tři redukčně pálené zlomky čelní prořezávané stěny (obr. 12). Deset zlomků plášt’ů nebylo bohužel možné přiřadit k žádnému konkrétnímu typu kachlů.
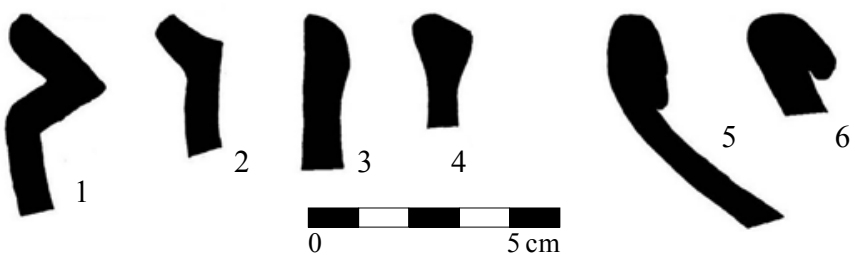

Obr. 11. Fragmenty kachlů. 1-4 - okraje nádobkových kachlů; 5-6 - okraje zadního vyhř́vacího otvoru. Kresba E. Ventrubová.

Abb. 11. Kachelfragmente. 1-4 - Topf kachelränder; 5-6 - Ränder der hinteren Blattöffnung. Zeichnung E. Ventrubová.
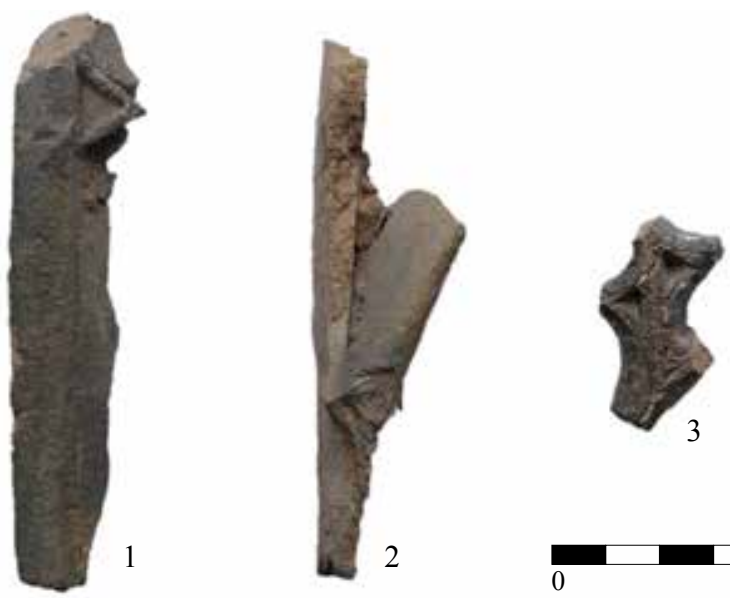

Obr. 12. Zlomky prořezávaných stěn. Foto L. Hobl.

Abb. 12. Fragmente durchschnittener Wände. Foto L. Hobl. 


\section{Motivy čelních vyhřívacích stěn komorových kachli̊}

Je velmi zajímavé, že i v relativně malém souboru, navíc získaném pouze povrchovým sběrem, bylo možné identifikovat poměrně široké spektrum motivů (celkem osm). Jejich stručný popis je obsahem následující části.

\section{Motiv tzv. meluziny}

$\mathrm{Na}$ jednom zlomku ČVS se vyskytuje část trupu a hlava ryby, která má otevřenou tlamu (obr. 13). Dále je dobře zřetelný okraj štítu, v němž byla scéna umístěna. Roh zřejmě vyplňovala šípatka, z níž je viditelný jeden lístek. Podle všeho by se mohlo jednat o motiv meluzíny, konkrétně o variantu, kde ryby již pohltily nohy a je viditelná pouze horní část postavy (více o motivu Hazlbauer 1989; Nejedlý 2002). Zpracováním je motiv nejbližší exemplářům nalezeným v Kralovicích (Pavlík 2017, obr. 667, 432) a u Mukařova u Ř́ćcan (Brych 2004, obr. 186, 95). Tento motiv byl jako jediný ze zde popisovaných již uveden v publikaci J. Orny věnované kachlům ze sbírek Západočeského muzea (Orna 2005, 77). Určení motivu jako tzv. meluzíny není bez pochyb. S menší pravděpodobností by se však mohlo také jednat o motiv s prorokem Jonášem.

\section{Motiv českého lva}

S tímto motivem lze ztotožnit dva fragmenty. Na prvním je lví hlava s korunou v pozici en face a kaskádovitě utvářenou hřívou (obr. 14). Na druhém jsou dvě nohy opatřené drápy. Nejspíše se jedná o přední nohy a lze podle nich určit, že lev směřuje vpravo. Ovšem zda je na motivu lev kráčející nebo ve skoku, nelze z těchto dvou zlomků jednoznačně rozhodnout. Pokud by se jednalo o lva kráčejícího, tak podobně ztvárněný motiv známe např́iklad z Nového Města pražského (Brych 2004, obr. 14, 36) nebo Pardubic (Pavlík 2017, obr. 1059, 458). Př́ímá analogie varianty není autorům známa, obdoby ovšem známé jsou. Například motiv korunovaného lva ve skoku v pozici en face pochází patrně z Plzně (Orna 2005, tab. 15:4, 37). Od vrtebské verze se však motiv liší (stejně jako $\mathrm{v}$ jiných případech) ztvárněním lví hřívy.

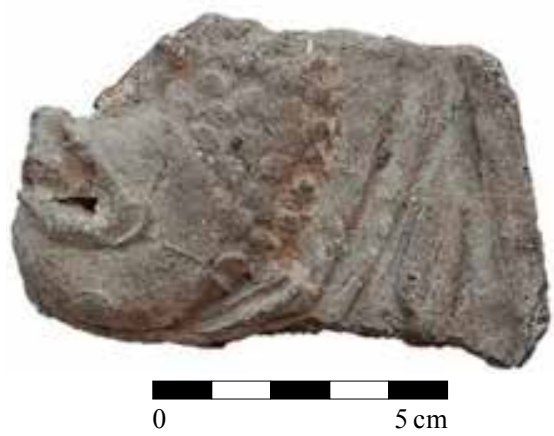

Obr. 13. Motiv meluzíny. Foto L. Hobl.

Abb. 13. Motiv der Melusina. Foto L. Hobl.
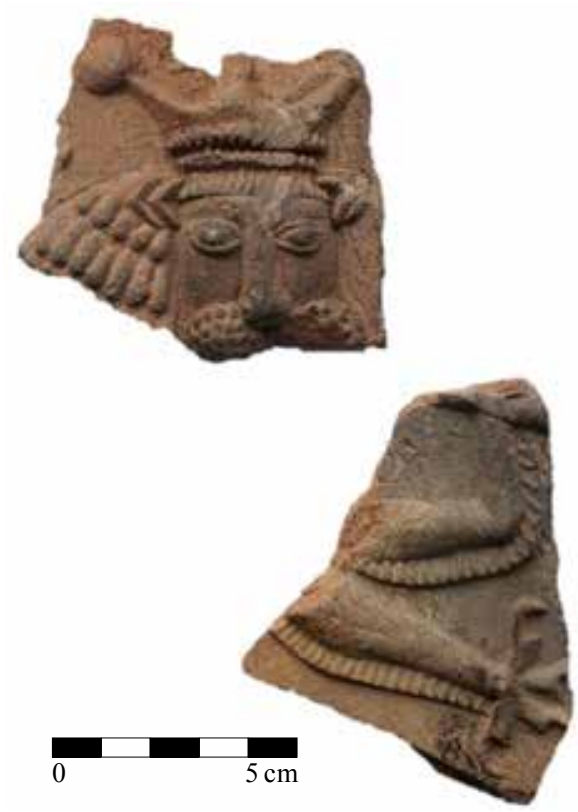

Obr. 14. Motiv českého lva. Foto L. Hobl.

Abb. 14. Motiv des böhmischen Löwen. Foto L. Hobl.

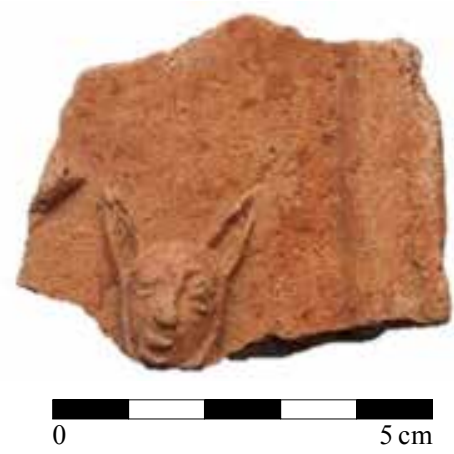

Obr. 15. Motiv turnajové scény. Foto L. Hobl. Abb. 15. Motiv einer Turnierszene. Foto L. Hobl. 


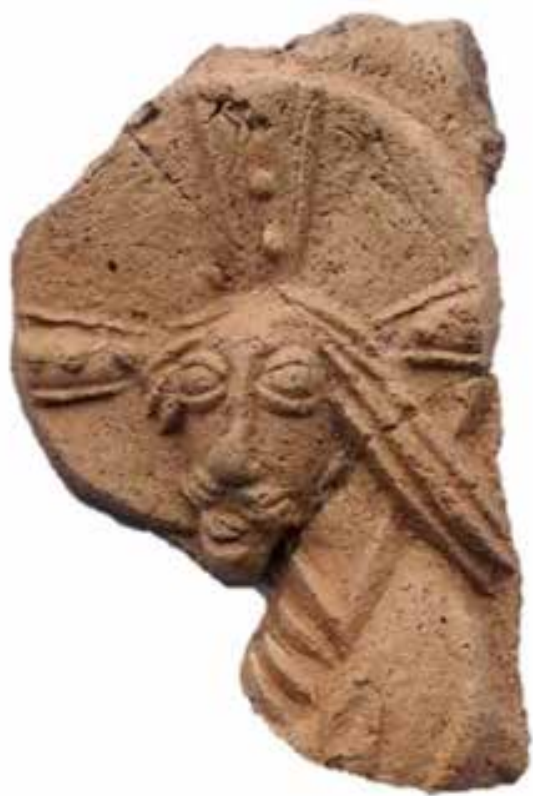

0

$5 \mathrm{~cm}$

Obr. 16. Neznámý motiv s Ježíšem v dospělé podobě. Foto L. Hobl.

Abb. 16. Unbekanntes Motiv mit Jesus als Erwachsener. Foto L. Hobl.

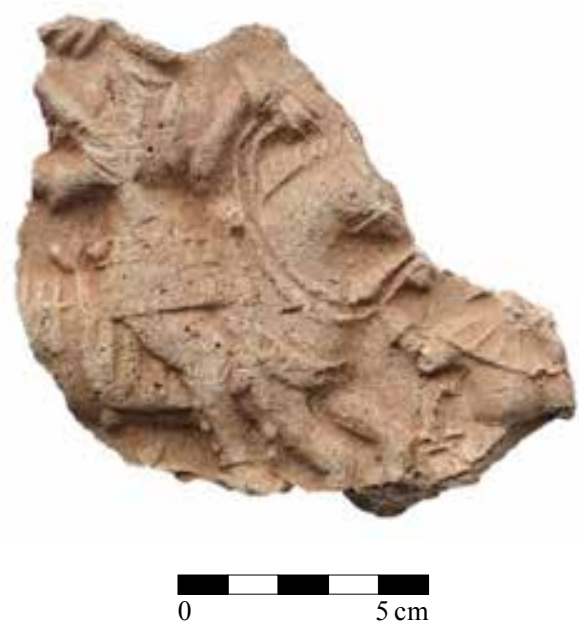

Obr. 17. Neznámý motiv jezdce se zbrojnošem. Foto L. Hobl. Abb. 17. Unbekanntes Motiv eines Reiters mit Waffenträger. Foto L. Hobl.

\section{Motiv turnajové scény}

K reliéfu turnaje může být přiřazen jeden zlomek ČVS. Je na něm hlava šaška s typickýma oslíma ušima (obr. 15). Nalevo je také patrná část bláznovského žezla, které interpretaci motivu kachle podporuje. Vpravo od hlavy je okraj ČVS. Na základě analogií je tedy pravděpodobné, že rytír směřoval právě k této straně (Pavlík-Vitanovský 2004, 91-93，239-240). Relativně malá velikost zlomku a absence většiny ČVS znemožňuje dohledání bližších analogií.

\section{Motiv s Ježišem v dospělé podobě}

Mezi střepy kachlů jsou prrítomny tři fragmenty, jež dohromady zobrazují část postavy s hlavou (obr. 16). Dobře patrné jsou na obličeji vousy a dlouhé vlasy. Viditelná část těla je zahalena oděvem a hlava je obklopena kř́ižovou svatozáríí. Tento kř́žžový nimbus napovídá, že se jedná o Ježíše Krista (Hazlbauer 1997, 345). Vzhledem k velikosti postavy by se mohlo jednat např́klad o motiv modlitby v Getsemanské zahradě, tuto domněnku však není možné jakkoliv ověřit.

\section{Motiv jezdce se zbrojnošem}

Reliéf s jezdcem a zbrojnošem je složen ze dvou fragmentů. Jezdec držící uzdu má nohu opatřenu ostruhou a $\mathrm{v}$ ruce trrímá blíže neurčitelný předmět (může se jednat o palcát nebo žezlo; obr. 17). Zbrojnoš, jenž přidržuje jezdci uzdu, je ozbrojen tesákem se záštitou a krk mu chrání plechový límec. Ani u jedné z postav se nedochovala hlava (pouze u jezdce je rozpoznatelná brada a rovněž nalevo od ní část vlasů), takže přesné určení motivu není možné. Nejblíže se však takovéto rozložení postav a celkový obsah blíží motivům označovaným jako „s Janem Žižkou“ či „,s neznámým hejtmanem". Na motiv s husitskou tematikou by rovněž odkazovala výzbroj a výstroj zbrojnoše (srov. Pavlík-Vitanovský 2004, 97-98). Tato varianta prozatím nebyla dosavadními souhrnnými pracemi zaznamenána.

\section{Motiv s postavou krále}

$\mathrm{Na}$ dvou zlomcích je v souboru přítomno vyobrazení těla postavy třímající v ruce královské jablko (obr. 18). Poměrně malé rozměry tohoto torza $(5,3 \mathrm{~cm}$ na výšku a $3,5 \mathrm{~cm}$ na šířku) nabízejí možnost jej identifikovat jako 


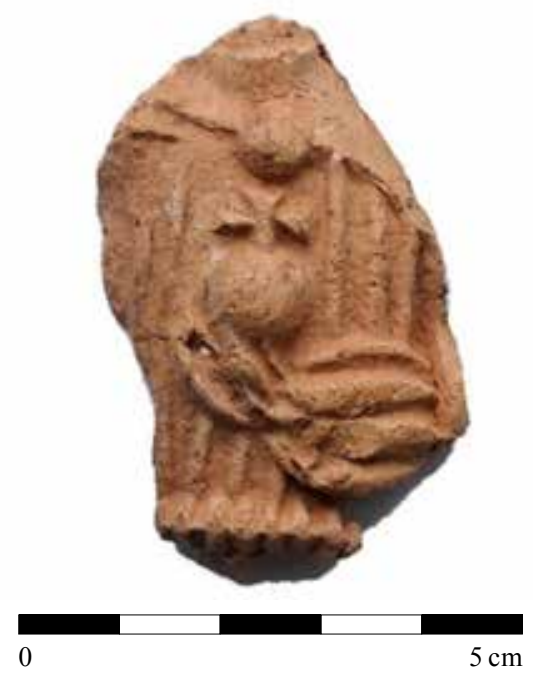

Obr. 18. Neznámý motiv s postavou krále. Foto L. Hobl. Abb. 18. Unbekanntes Motiv mit Gestalt des Königs. Foto L. Hobl. postavu z nějakého náboženského motivu, např́iklad Korunovace Panny Marie (podle analogií se zdá být nejpravděpodobnější) nebo Klanění tří králů (srov. Pavlík-Vitanovský 2004, 37-38, 57, obr. 109-118, obr. 348-352).

\section{Ornamentální rozeta $v$ medailonu}

Mezi ČVS dominuje počtem devíti fragmentů motiv s rozetou v medailonu (obr. 19). Středovou rozetu tvořilo osm lístků kapkovitého tvaru. Tento střed obklopuje medailon o dvou úrovních. Vnitřní část představuje $2 \mathrm{~cm}$ široký plastický pás navozující dojem tordování. Vnější část ohraničuje lišta, ve které se objevují kromě plastických kuliček také lipové lístky. Takové motivy jsou spojovány s pronikajícími znaky renesance (Pavlík-Vitanovský 2004, 432-433). Popsaná varianta se zatím v odborné literatuře neobjevila.

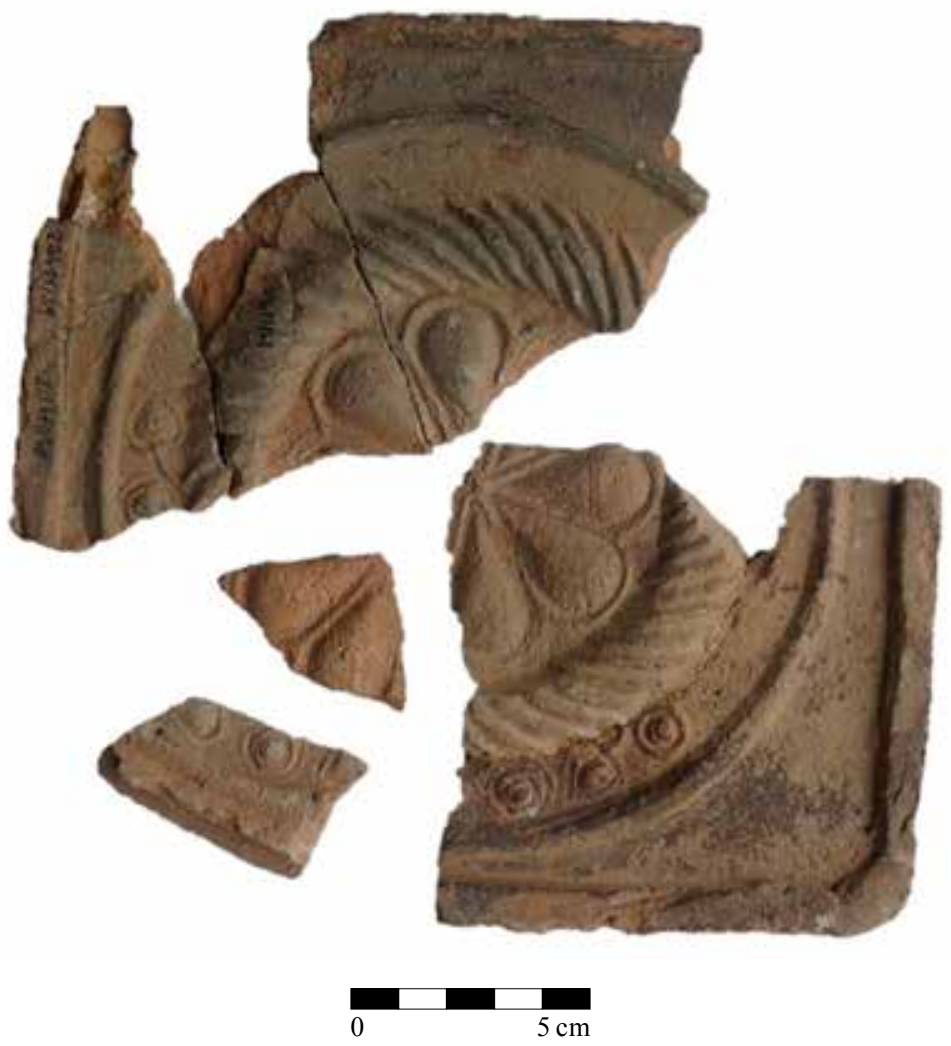

Obr. 19. Motiv ornamentální rozety v medailonu. Foto L. Hobl.

Abb. 19. Motiv einer Zierrosette im Medaillon. Foto L. Hobl. 


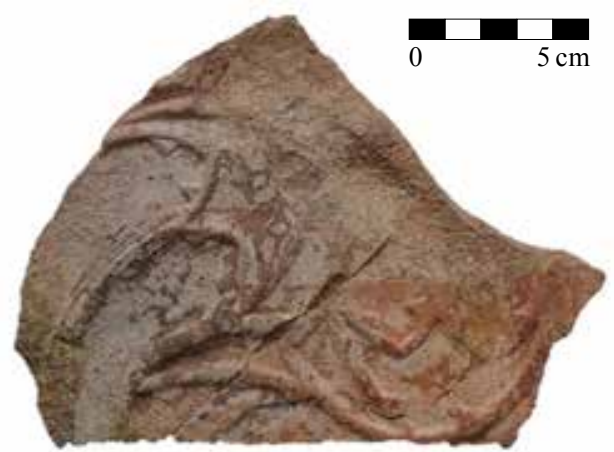

Obr. 20. Motiv architektonické rozety. Foto L. Hobl. Abb. 20. Motiv einer architektonischen Rosette. Foto L. Hobl.
Motiv gotické kružby

Posledním určitelným motivem identifikovaným na čtyřech zlomcích ČVS je kružbová kompozice tvořená architektonickou rozetou (obr. 20). Centrální (?) rozetu vytváří tři dvojité rotující plaménky. $Z$ důvodu absence okrajů tohoto kachle nemůžeme blíže stanovit jeho tvar ani rozměry, a není proto jednoduché určit analogii. Pokud by se jednalo o centrální motiv, byla by rozeta ztvárněna obdobně jako varianta nalezená na předměstí v Sezimově Ústí. Zde se však jednalo o kachel s prořezávanou čelní stěnou (Pavlík 2017, obr. 1417, 482).

\section{Zhodnocení souboru kamnářské keramiky}

Předložený soubor kamnářské keramiky představuje exkurz do vnitřního zařízení obytných místností hradu Vrtba. Bohužel fragmentárnost souboru pochopitelně neumožňuje bližší poznání tohoto druhu otopných zařízení. Všechny výše popsané reliéfy na komorových kachlech jsou datovatelné převážně do druhé poloviny 15. století s přesahem do první poloviny 16. století (zejména motiv s ornamentální rozetou). Zlomkovitost ostatních druhů kachlů, nádobkových s pravoúhlým ústím a výklenkových, bližší dataci neumožňuje.

\section{Srovnání s jinými soubory}

Vzhledem k poloze lokality a sociálnímu prostředí se nabízí možnost porovnat tento materiál se dvěma publikovanými soubory kachlů z Rabštejna nad Střelou a z Gutštejna.

Rabštejn nad Střelou je od hradu Vrtba vzdálen vzdušnou čarou asi $18 \mathrm{~km}$ na sever. V rámci srovnání je nutné zmínit, že soubor z Rabštejna pochází z povrchového sběru a je tvořen poměrně malými fragmenty, podobně jako na Vrtbě, což limituje jeho přesnější hodnocení. Na obou lokalitách jsou zastoupeny komorové reliéfní kachle, nádobkové kachle s pravoúhlým ústím a kachle výklenkové (Hazlbauer 1995, 12-24). Soubory obsahují reliéfy ČVS s heraldickými, náboženskými a mytologickými náměty. Některé z těchto motivů jsou obdobné, např́íklad český lev nebo meluzína, i když jejich varianty se od vrtbovských liší. V souboru z Rabštejna však na rozdíl od Vrtby absentují reliéfy světské a ornamentální. Reliéfní kachle jsou datovány do druhé poloviny 15. století, př́ípadně do začátku 16. století (Hazlbauer 1995, 13-21), což časově koresponduje se souborem z Vrtby. Tato datace nicméně odpovídá velké části obdobných souborů reliéfních kachlů. Soubory se liší mnohem výraznějším zastoupením výklenkových kachlů v nálezech z Rabštejna, které může naznačovat přítomnost celých kamen tvořených tímto typem kachlů. Jejich zpracování bylo poměrně kvalitní a umožňuje předpokládat dataci do druhé poloviny 14. až první čtvrtiny 15. století (Hazlbauer 1995, 21-22). Rozdíly mezi nádobkovými kachli s pravoúhlým ústím nelze na základě literatury postihnout, jelikož jim z pochopitelných důvodů nebyla věnována větší pozornost (srov. Hazlbauer 1995, 23-24).

V obdobné vzdálenosti od Vrtby jako Rabštejn se asi $17 \mathrm{~km}$ vzdušnou čarou směrem na západ nachází hrad Gutštejn. Publikovaný soubor zdejších kachlů pochází z archeologického výzkumu E. Kamenické (Hobl 2016, 461). Srovnání je možné hlavně se soubory 1 a 2, které se svou datací blíží souboru z Vrtby (2. polovina 15. až počátek 16. století). Stejně jako v předchozím př́ípadě i na Gutštejně jsou zastoupeny komorové kachle s reliéfní ČVS, nádobkové kachle s pravoúhlým ústím a části výklenkových kachlů, resp. jejich prořezávaných stěn. Na ČVS se, stejně jako v souboru z Vrtby objevují motivy náboženské, heraldické, ornamentální, architektonické 
a světské, naopak chybějí náměty mytologické. Žádný z konkrétních motivů se však neshoduje. Motiv ornamentální rozety (obr. 13) se jeví mladší než oba soubory z Gutštejna, oproti souboru 3 ale působí více archaicky, a to jak použitým materiálem, tak i absencí glazury (srov. Hobl 2016, obr. 14:A-C, 469). V obecné rovině je možné konstatovat, že gutštejnský soubor 1 je kvalitou zpracování na vyšší úrovni než soubor z Vrtby; ČVS byly navíc překryty zelenou glazurou, což je pro toto období méně obvyklý jev. Soubor 2 je v tomto ohledu srovnatelné úrovně (Hobl 2016, 462-468). Porovnání nádobkových kachlů s pravoúhlým ústím je vzhledem k fragmentárnosti obtížné a znemožňuje porovnat rozměry. Známé profilace $\mathrm{z}$ obou hradů jsou značně rozdílné s výjimkou těch jednodušších, které jsou si pochopitelně podobnější (srov. obr. 6:3 a Hobl 2016, obr. 8:F). Výklenkové kachle jsou v obou případech prezentovány pouze třemi zlomky čelních prořezávaných stěn. Ve vrtbovském souboru se nacházejí dvě okrajové části a jedna středová, zatímco v gutštejnském jsou to tři středové části (Hobl 2016, obr. 13:D-F). Shodná je inspirace gotickou architekturou, což je ale u tohoto druhu kachle poměrně obvyklé. Rozdílná je technologie výroby, jelikož na Gutštejně byly tyto výrobky páleny oxidačně, zatímco na Vrtbě zaznamenáváme pouze výpal redukční.

\section{Kovový artefakt}

Soubor obsahuje pouze jediný železný nález. Jedná se o obdélnou plechovou destičku prohnutou po delší straně se zaoblenými rohy (obr. 21). V jednom z rohů je dírka po chybějícím nýtu. V dalších dvou rozích je při detailním zkoumání umístění nýtů patrné. Jeden z rohů, kde se dá předpokládat čtvrtý otvor, se bohužel nedochoval. Tuto destičku lze interpretovat jako lamelu $\mathrm{z}$ brigantiny.

\section{Závěr}

Hrad Vrtba náleží mezi početné šlechtické hrady vzniklé v období na přelomu 13. a 14. století. Souvisí s mocenským vzestupem rozrodu Hroznatovců, kteří si v krátké době postavili větší množství hradů, po nichž se poté psaly jednotlivé větve (např. Bělá, Gutštejn, Frumštejn atd.). Další plánovaný výzkum hroznatovské domény umožní hlubší poznání vývoje regionu a její porovnání s jinými oblastmi Čech, kde je poznání proměny šlechty mezi raným a vrcholným středověkem prohloubenější - například střední Pojizeří (Markvartici), severozápadní Čechy (Hrabišici) nebo jižní Čechy (Rožmberkové, resp. Vítkovci).

Současný stav lokality bohužel neumožňuje bližší poznání hradního jádra, o to cennější jsou ovšem relikty obvodového opevnění, a hlavně rybniční soustavy s mlýnem. Velmi zajímavé

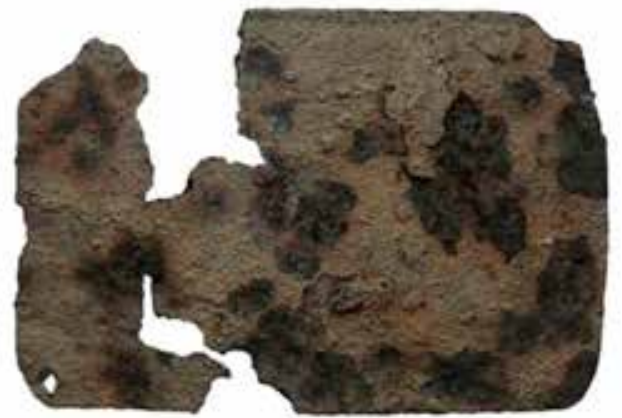

0 $5 \mathrm{~cm}$

Obr. 21. Lamela $z$ brigantiny. Foto L. Hobl. Abb. 21. Lamelle von einer Brigantine. Foto L. Hobl. je také rozptýlené ekonomické zázemí v poslední čtvrtině 14 . století, které jasně demonstruje, že pro existenci hradu nebylo potřeba, aby se vesnice nacházely $\mathrm{v}$ jeho bezprostřední blízkosti. To část odborníků považuje za nutné již pro období počátků šlechtických hradů (např. Razím 2004, 177). Více př́íkladů ze sledované oblasti ukazuje, že pro běžný provoz vystačilo pouze předhradí, př́ípadně hospodářský dvůr, zatímco vesnice tvořící zázemí mohly být i ve značné vzdálenosti (např. vesnice Líšt’any se nachází $12 \mathrm{~km}$ vzdušnou čarou od Gutštejna). ${ }^{35}$ Nutnost kompaktní domény

35 Citovaná diskuse o hospodářském zázemí hradů proběhla na stránkách Archeologických rozhledů před více než 15 lety. Naším cílem není její celkové vyznění rozporovat, nýbrž pouze upozornit, že některé z použitých argumentů nejsou zcela relevantní. 
se objevila až s obdobím pozdního středověku a přímo souvisela s podnikatelskými aktivitami šlechty (srov. Polívka 1991). Podobné slučování do velkých domén se ostatně hradu Vrtba stalo osudným. V polovině 16. století ztratil hrad sídlení funkci a přestal sloužit jako centrum panství. Nedlouho poté zanikl úplně a nadále byl využíván jen hospodářský dvůr, který představoval hospodářskou jednotku, z níž plynuly zisky.

Bez zajímavosti rovněž není soubor nálezů získaných povrchovými sběry, a to hlavně kamnářské keramiky, která ukazuje rozmanitost reliéfních motivů na komorových kachlích a zprostředkovává elementární představu o vybavení vnitřních prostor hradu. Rámcová datace starší skupiny kuchyňské a stolní keramiky koresponduje s obdobím, kdy se hrad poprvé objevuje v písemných pramenech (1316). Nicméně zároveň není možné vyloučit, že byl založen již dříve.

Tato studie je dílčím výsledkem projektu Studentské grantové soutěže Západočeské univerzity v Plzni SGS-2016-068 „Studium vybraných sídelních struktur dlouhého trvání v západních a jižních Čechách“.

\section{Prameny}

AČ 3: Archiv český 3 (Palacký, F., ed.). Praha 1844.

AČ 6: Archiv český 6 (Palacký, F., ed.). Praha 1872.

CDB I: Codex diplomaticus et epistolaris regni Bohemiae I. (Friedrich, G., ed.). Praha 1904-1907.

DD VII: Desky dvorské království českého VII. (Friedrich, G., ed.). Praha 1929.

DZ I/1: Desky zemské království českého I/1. (Vavroušková, A., ed.). Praha 1941.

Bernaregister: Ein Bernaregister des Pilsner Kreises vom Jahre 1379 (Emler, J., ed.). Praha 1876.

LC I/2: Libri Confirmationum ad beneficia ecclesiastica Pragensem per archidioecesim I/2. (Emler, J., ed.). Praha 1874

LE V: Libri erectionum archioecesis Pragensis V. (Borový, C., ed.). Praha 1889.

Listář II: Listář královského města Plzně a druhdy poddaných osad II. (Strnad, J., ed.). Plzeň 1905.

NA, ČG - GL: Národní archiv, České gubernium - Guberniální listiny, inv. č. 637 (inventář fondu).

NA, Mapová sbírka II.: Národní archiv, Sbírka map a plánů, inv. č. 1065, sign. F IX 17.

PZD I: Pozůstatky desk zemských království českého r. 1541 pohořelých I. (Emler, J., ed.). Praha 1870.

RBM I: Regesta diplomatica nen non epistolaria Bohemiae at Moraviae I. (Erben, K. J., ed.). Praha 1855.

RBM IV: Regesta diplomatica nec non epistolaria Bohemiae et Moraviae IV. (Emler, J., ed.). Praha 1892.

\section{Literatura}

ANDERLE, J.-MILER, J., 1985: Vrtba, k. ú. Vrtbo, o. Plzeň-sever, Ročenka KAS 85, 112-119.

BRYCH, V., 2004: Kachle doby gotické, renesanční a raně barokní. Výběrový katalog Národního muzea v Praze. Praha.

D[VORSK]Ý, F., 1874: Pamět' o pánech z Bělé a z Gutštejna (1437), PA X, 177n.

FOUD, K.-KAREL, T., 1993: Zaniklá středověká osada Štěpánovice. K. ú. Lhotka, okr. Plzeň-sever. In: Severní Plzeňsko I., 38-40. Mariánská Týnice.

FRIDRICH, J., 1970: Z minulosti velkostatku Nekmíře, Minulostí západočeského kraje VII, 221-242.

GALUSOVÁ, L., 2011: Archeologický výzkum vodních mlýnů: výsledky a perspektivy, AntropoWebzin 2, $113-120$.

HAZLBAUER, Z., 1989: Motiv mořské víly - Meluzíny - v ikonografii českých reliéfních kachlů - Das Motiv der Nixe Melusine in der Ikonographie tschechischer gotischer Reliefkacheln, AH 14, 409-436.

- 1995: Historické kamnové kachle z Rabštejna nad Střelou. Vlastivědná knihovnička Společnosti přátel starožitností sv. 2. Praha.

- 1997: Zobrazení Ježíše v dospělé podobě na českých reliéfních kachlích - Darstellung Jesu Christi in seiner erwachsenen Gestalt auf den böhmischen gotischen Reliefkacheln, AH 22, 345-362.

HOBL, L., 2011: Hroznatovské hrady Dolní Bělá a Vrtba. Rkp. bakalářské práce, ulož. na KAR FF ZČU.

- 2016: Kachle z hradu Gutštejna - Kacheln von Burg Guttenstein, AH 41, 461-473.

HOJDA, Z.-PEŠEK, J., 1979: Osídlení a feudální rozdrobenost v plzeňském kraji (na základě berního rejstříku z roku 1379), HG 18, 103-157.

JÁNSKÝ, J., 2009: Hroznatovci a páni z Gutštejna. Domažlice. 
JOHN, J., 2010: Výšinné lokality středního eneolitu v západních Čechách. Plzeň.

KOČKA, V., 1932: Dějiny politického okresu kralovického. Díl 2. Soudní okres manětínský. Kralovice.

KODERA, P., 2007: Neznámá ikonografie zámku Bělá. In: Dějiny staveb 2007, 101-107. Plzeň.

MACHÁČEK, F., 1929: Vývoj hospodářský a sociální v okrese plzeňském. In: Plzeň a Plzeňsko II., 29-56. Plzeň.

NEJEDLÝ, M., 2002: Od krásné dívky až k hadům a drakům. Proměny víly Meluzíny a jejich obraz v ikonografii středověkých pramenů, AR LIV, 457-494.

NOVÁ, K., 2004/2005: Hrad Vrtba a jeho majitelé, Kronika regionu Kralovicko-Manětínsko-Plasko 3, č. 2, $10-11$.

NOVÁČEK, K. et. al., 2010: Kladrubský klášter 1115-1421. Osídlení - architektura - artefakty. Plzeň.

ORNA, J., 2005: Gotické a renesanční kachle ve sbírkách Západočeského muzea v Plzni. Plzeň.

PAVLÍK, Č., 2017: Velký obrazový atlas gotických kachlových reliéfů: Čechy, Morava, české Slezsko. Praha.

PAVLÍK, Č.-VITANOVSKÝ, M., 2004: Encyklopedie kachlů v Čechách, na Moravě a ve Slezsku. Praha. PODLAHA, A., 1909: Posvátná místa království českého. Arcidiecese pražská. III. Praha.

POLÍVKA, M., 1991: Šlechtic jako podnikatel v pozdně středověkých Čechách. In: Pocta Josefu Petráňovi. Sborník prací z českých dějin k 60. narozeninám prof. Dr. Josefa Petráně (Beneš, Z.-Maur, E.-Pánek, J., edd.), 95-111. Praha.

PROFOUS, A., 1954: Místní jména v Čechách 1. A-H. Praha.

RAZÍM, V., 2004: Nad počátky hradů české šlechty, AR LVI, 176-214.

ROŽMBERSKÝ, P., 1993: Stav poznání středověkých zaniklých vesnic na území okresu Plzeň-sever. In: Severní Plzeňsko I., 1-37. Mariánská Týnice.

- 1999: O berním rejstříku Plzeňského kraje z roku 1379. In: Rozpravy Klubu Augusta Sedláčka 1. Plzeň.

- 1999a: Dvory plaských cisterciáků. Zapomenuté hrady, tvrze a místa 21. Plzeň.

ROŽMBERSKÝ, P.-NOVOBILSKÝ, M., 2007: Gotická tvrz a zámecká pevnost Kaceřov. Zapomenuté hrady, tvrze a místa 36. Plzen̆.

SEDLÁČEK, A., 2000: Hrady, zámky a tvrze Království českého, I-XV. CD-ROM. První elektronické vydání.

SVOBODA, J., 1995: O pláštových hradech - Die Burgen mit Mantelmauern, AH 20, 355-388.

SCHMIDT, G., 1928: Bürgen Westböhmens. II. Teil, Beschreibung und Geschichte. Mies.

ŠIROKÝ, V., 1930: Manětínsko. Dolní Bělá.

- 1936: Na Pekýlci, Vlastivědný sborník okresu rakovnického s Křivoklátskem a okresu kralovického s Manětínskem 7, č. 1, 5-7; č. 2, 19-20; č. 3, 30-31.

ÚLOVEC, J.-JÁNSKÝ, J., 2000: Hrad Gutštejn, Západočeský historický sborník 6, 75-103.

TEIGE, J., 1915: Základy starého místopisu Pražského (1437-1620) II. Praha.

\section{Zusammenfassung}

\section{Burg Vrtba und ihr wirtschaftliches Hinterland}

Die Burg Vrtba gehört zu einer der zur Wende des 13. und 14. Jahrhunderts entstandenen Burgen. Sie hängt mit der zunehmenden Verzweigung der Familie Hroznatovci zusammen, die binnen kurzer Zeit eine Fülle von Burgen errichtete, nach denen sich danach die einzelnen Familienzweige schrieben (z.B. Bělá, Guttenstein, Frumstein usw.). Der derzeitige Zustand der Fundstelle ermöglicht leider keine näheren Erkenntnisse über die Bebauung der Kernburg zu gewinnen, um so wertvoller sind jedoch die Geländerelikte der Einfriedungsbefestigung und das Hauptteichsystem mit einer Mühle. Sehr interessant ist auch die Herrschaft der Burg, die im letzten Viertel des 14. Jahrhunderts sehr verstreut war. In jüngerer Zeit erlauben es schriftliche Quellen, die Veränderung ihrer Struktur zu beobachten, die zur Bildung einer kompakten Domäne führte. Dieses Phänomen tauchte erst mit der Zeit des Spätmittelalter auf und hing unmittelbar mit den unternehmerischen Aktivitäten des Adels zusammen. Eine solche Zusammenlegung zu großen Domänen stand schließlich auch hinter dem Untergang dieser Burg. Mitte des 16. Jahrhunderts wurde die Burg mit der Herrschaft verkauft und diente nicht länger als Zentrum des Dominiums und verlor auch ihre Residenzfunktion. Nicht lange danach verschwand sie vollständig und man nutzte nur noch den Wirtschaftshof, der fernerhin eine Wirtschaftseinheit 
darstellte, aus der Gewinne flossen. Von den durch Oberflächensammlung gewonnenen archäologischen Quellen ragt vor allem eine Kollektion an Ofenkeramik hervor. Sie präsentiert eine Vielfalt an Reliefmotiven auf Blattkacheln und macht es möglich, sich zumindest teilweise eine Vorstellung davon zu machen, wie der Innenraum der Burg ausgestattet war.

Die vorliegende Studie ist ein Teilergebnis des Studentischen Förderwettbewerbprojektes der Westböhmischen Universität in Pilsen SGS-2016-068 „Studium ausgewählter und nachhaltiger Siedlungsstrukturen in West- und Südböhmen“.

Mgr. Luboš Hobl, Katedra archeologie Filozofické fakulty Západočeské univerzity, Sedláčkova 15, 30614 Plzeň, Česká republika, hobll@kar.zcu.cz; Hobl.l@seznam.cz, tel. 420606194567

Mgr. Pavel Kodera, Ph.D., Národní technické muzeum, Centrum stavitelského dědictví Plasy, Pivovarská 5, 33101 Plasy, Česká republika, pavel.kodera@ntm.cz, tel. 420373300734 
